2 Pollination and reproduction of an invasive plant inside and outside its

3

4

5

6

\title{
ancestral range
}

\section{Theodora Petanidou ${ }^{\mathrm{a}^{*}}$, Mary V. Price ${ }^{\mathrm{b}}$, Nickolas M. Waser ${ }^{\mathrm{b}}$, Aphrodite Kantsa ${ }^{\mathrm{a}}$, Thomas}

Tscheulin $^{\mathrm{a}}$, Rupesh Kariyat ${ }^{\mathrm{c}}$, Nickolas Krigas ${ }^{\mathrm{d}}$, Mark C. Mescher ${ }^{\mathrm{e}}$, Consuelo M. De

\section{Moraes $^{e}$, Judith L. Bronstein ${ }^{\mathrm{f}}$} 8

${ }^{\mathrm{a}}$ Laboratory of Biogeography and Ecology, Department of Geography,

University of the Aegean, University Hill, GR-81100 Mytilene, Greece

1 School of Natural Resources and the Environment, University of Arizona, 2 Tucson, AZ 85721, USA

$3{ }^{\mathrm{c}}$ Department of Biology, University of Texas Rio Grande Valley, Edinburg, 4 TX 78539, USA.

$5{ }^{\mathrm{d}}$ Department of Ecology, School of Biology, Aristotle University of

6 Thessaloniki, GR-54124, Thessaloniki, Greece

17 e Department of Environmental Systems Science, ETH Zürich, 8092 Zürich,

8 Switzerland

9 f Department of Ecology and Evolutionary Biology, University of Arizona,

Tucson, AZ 85721, USA

* To whom correspondence should be addressed. E-mail:

2 t.petanidou@aegean.gr 
- Weedy Solanum elaeagnifolium is invasive outside its ancestral North America range.

- We compared its sexual reproduction in Arizona, USA (“AZ”) and Greece (“GR”).

- Pollination in GR was by native bees that resemble ancestral AZ pollinators.

- GR plants invest more in flowers and ovules but do not produce more seeds.

28 - These results suggest promising avenues for further research. 


\section{Abstract}

Comparing traits of invasive species within and beyond their ancestral range may improve our understanding of processes that promote aggressive spread. Solanum elaeagnifolium (silverleaf nightshade) is a noxious weed in its ancestral range in North America and is invasive on other continents. We compared investment in flowers and ovules, pollination success, and fruit and seed set in populations from Arizona, USA (“AZ”) and Greece (“GR”).

In both countries, the populations we sampled varied in size and types of present-day disturbance. Stature of plants increased with population size in AZ samples whereas GR plants were uniformly tall. Taller plants produced more flowers, and GR plants produced more flowers for a given stature and allocated more ovules per flower. Similar functional groups of native bees pollinated in AZ and GR populations, but visits to flowers decreased with population size and we observed no visits in the largest GR populations. As a result, plants in large GR populations were pollen-limited, and estimates of fecundity were lower on average in GR populations despite the larger allocation to flowers and ovules. These differences between plants in our AZ and GR populations suggest promising directions for further study. It would be useful to sample S. elaeagnifolium in Mediterranean climates within the ancestral range (e.g., in California, USA), to study asexual spread via rhizomes, and to use common gardens and genetic studies to explore the basis of variation in allocation patterns and of relationships between visitation and fruit set.

\section{Keywords}

Ancestral range; Bees; Invaded range; Pollination success; Sexual allocation; Solanum elaeagnifolium 


\section{Introduction}

The introduction of species beyond their ancestral range often causes ecological damage, and aggressive spread of invasive species threatens biodiversity worldwide (Elton 1958; Pimentel et al. 2001; Traveset and Richardson 2006). Studies of species invasions suggest that they depend both on attributes of the invaders and of the invaded systems, but much about what promotes successful invasion remains a mystery (Richardson and Pysek 2006; Tanentzap et al. 2010; van Kleunen et al. 2010).

Comparison across populations of invasive species within and beyond their ancestral range may indicate ways in which individual traits have changed during invasion, thus offering insight into factors that promote or accompany geographic spread. Few studies have attempted such a comparison for plants, and most of these have focused on success in recruitment and on genetic variance in invading populations (De los Santos et al. 2001; Lafuma and Maurice 2007; Mandák et al. 2009; Colautti et al. 2011). Fewer have compared aspects of pollination and reproduction (e.g., Caño et al. 2008, Li et al. 2012, Atlan et al. 2015), and to our knowledge only three such were carried out in the wild (Stout et al. 2006; Petanidou et al. 2012; Montero-Castaño et al. 2014).

As a first step in exploring factors that might relate to the invasion success of Solanum elaeagnifolium, a noxious weed, we examined components of its present-day sexual reproduction in a sample of populations of different size and ecological context within and beyond the ancestral range. Determining a potential invader's ability to reproduce is critical, because propagule supply is essential for the founding and maintenance of populations (Barrett 2011). We measured (1) traits related to plants' initial investment of resources 
toward pistillate (female) sexual function (i.e., investment in flowers and ovules); (2) pollinator visits and pollination success; and (3) components of realized fecundity (i.e., fruit and seed production). The patterns that emerge indicate that plants sampled in the invaded range allocated more resources to flowers and ovules than those in the ancestral range, but received fewer visits from pollinators and did not produce more seeds. We suggest possible reasons for these results and some avenues for further research.

\section{Materials and methods}

\subsection{Study species}

Solanum elaeagnifolium Cav. (silverleaf nightshade, Solanaceae) is a short-lived perennial herb with an ancestral range in the southwest to west-central USA and northern Mexico. By the 1970s the species had spread throughout the USA (Kearney et al. 1969; Munz 1974; Boyd et al. 1984; Mekki 2007) and to all continents except Antarctica (Tscheulin et al. 2009; Brunel et al. 2013). Plants often act as ruderals that colonize disturbed sites (USDA 2006; Tscheulin et al. 2008, 2009). The blue-to-lilac hermaphroditic flowers are nectarless and are pollinated mostly by bees that vibrate their wings to release pollen from the anthers ("buzz" pollination, Buchmann and Cane 1989). Plants appear to be predominantly self-compatible in Arizona (USA), within the ancestral range, and predominantly self-incompatible in Greece, part of the invaded range (Petanidou et al. 2012). Mature fruits are small, dry, globose berries that can contain >100 seeds (Tscheulin et al. 2009; Petanidou et al. 2012). Plants contain teratogenic compounds that are toxic to livestock (Baker et al. 1989; Keeler et al. 1990), lower the yield of many co-occurring crops (Boyd et al. 1984), and reduce the pollination success of native plants (Tscheulin et al. 2009; Vilà et al. 2009; Tscheulin and Petanidou 2013). 
103 2.2. Study populations

104

105 We studied S. elaeagnifolium in southeastern Arizona, USA, and in Greece, where it was first

106 recorded in 1927 (Krigas and Kokkini 2004). In each country, we sampled accessible

107 populations that ranged in size and in the presence of other plant species, and that varied in

108 type of disturbance they experience. In total we chose 27 populations (Table 1), 9 in

109 southeastern Arizona (“AZ”) near the town of Marana and the Santa Rita Mountains in Pima

110 County, and near the towns of Willcox and San Simon in Cochise County; and 18 in Greece

111 ("GR") on the Island of Lesvos in the northeastern Aegean Sea and near the city of

112 Thessaloniki on the northern mainland.

114 To indicate different degrees of invasive spread we scored large monospecific stands with

$115>10,000$ plants (see Fig. S1) as "2" on an ordinal scale, monospecific stands with 2,000-

11610,000 plants as " 1 ", and small populations with $<2,000$ plants intermixed with other non-

117 crop species as “0” (see Fig. S2). Because S. elaeagnifolium can propagate vegetatively as

118 well as sexually (Cooley and Smith 1971; Buchmann and Cane 1989; Tscheulin et al. 2008,

119 2009) some "plants" were ramets of the same genet (= clone). It should be kept in mind that

120 when we refer here to "plants" we may in some cases be describing different ramets of the

121 same genet. We also scored populations on roadsides, rangelands, and wastelands that were

122 exposed to periodic mowing or trampling as receiving "surface disturbance", and those

123 associated with agricultural fields that were exposed to deeper soil turnover as being "tilled".

125 Population sizes and disturbance regimes differed between AZ and GR samples

126 (Table 1). In AZ we studied 3 small and 2 medium-sized populations that 
127

128

130

131

132

133

134

135

136

137

138

139

140

141

142

143

144

145

146

147

148

149

150 We studied pollinator visits during the peak flowering period of S. elaeagnifolium (June-

151 September) in 2006 in Arizona, 2006 and 2014 on Lesvos, and 2007 near Thessaloniki (Table

experienced surface disturbance, and one small, 2 medium-sized, and one large that were tilled. In GR we studied 3 small, 2 medium-sized, and 3 large populations that experienced surface disturbance and 9 large that were tilled. Thus there were more large monospecific stands among GR populations, and more monospecific stands among tilled populations.

\subsection{Investment in flowers and ovules}

In each study population we tagged 29-60 plants at random. We estimated the number of flowers produced by each tagged plant based on the number of fruits it ultimately produced (see Section 2.5) as:

$$
\text { \# flowers per plant }=\text { \# fruits per plant } \times(\text { mean \# OP flowers/mean \# OP fruits })
$$

where "\#” signifies "number of" and "OP" refers to open-pollinated flowers and fruits from an experimental study of pollen limitation (see Section 2.4). As a further measure of investment in female function we collected ovaries from 1-2 randomly-chosen flowers on each tagged plant and counted ovules. To estimate total per-plant ovule numbers we multiplied mean per-flower ovule count for each population by estimated flowers per plant for each tagged plant in that population.

\subsection{Pollinator visits and pollination success}


152 1). We surveyed each population several times (twice in Arizona and near Thessaloniki and

153 four times in Lesvos, all 20-30 days apart). During each survey we spent one or two days in

154 each population and took four 15-minute pollinator censuses on each day (total 60 or 120

155 minutes per population). During each census, we recorded the number of flower visits by

156 each insect that entered a transect $25 \mathrm{~m}$ long $\times 2 \mathrm{~m}$ wide. At noon each day we counted all

157 open flowers in the transect and from this calculated mean visits per flower per hour. All

158 observations were made on sunny calm days during peak insect activity, between 0600 and

$1591300 \mathrm{~h}$ in $\mathrm{AZ}$, and 0830 and $1500 \mathrm{~h}$ in GR. Although all populations were surveyed more

160 than once, we based analyses only on the survey that yielded the highest visitation to flowers.

161 This approach allowed us to compare the local maximum of flowering and pollination across

162 populations. The additional surveys of each population added to our sample of pollinators, as

163 did an additional 15 minutes spent after each census netting flower visitors outside of

164 transects. Collected specimens were identified to species whenever possible and are

165 deposited in the Melissotheque of the Aegean, Laboratory of Biogeography and Ecology,

166 University of the Aegean (Petanidou et al. 2013).

167

168 As a measure of pollination success, we calculated a Pollen Limitation Index (PLI) for each

169 population (Tscheulin and Petanidou 2013):

170

$171 \mathrm{PLI}=1-[$ (average \# seeds set after open pollination) $/$ (average \# of seeds set after pollen

172 addition)]

173

174 A value of 0 suggests that open pollination is maximally effective, whereas 1 represents

175 complete pollen limitation. We generated PLI values by marking 1-2 pairs of flower buds on

176 each of the 29-60 tagged plants in each population, and pollinating one of each pair chosen at 
177 random (pollen addition, "PA") while leaving the other untreated (open pollinated, "OP”).

178 Pollen was collected in the morning from several donor plants 5-20 $\mathrm{m}$ from each recipient

179 using a tuning fork or by shaking the anthers into a clean Petri dish, and was applied to

180 stigmas with a clean toothpick (Tscheulin et al. 2009; Petanidou et al. 2012). We counted

181 viable seeds in mature fruits 5-6 weeks later, and calculated the mean number of seeds per

182 fruit over all flowers receiving the same treatment in a population. In the few cases where

183 PLI was negative the value was set to zero before analysis.

184

$185 \quad 2.5$. Fruit and seed set

186

187 At the end of the flowering season we measured plant height of each of the 29-60 tagged

188 plants in each population to the nearest $\mathrm{cm}$, as a proxy for overall size. At the same time we

189 counted all fruits produced by each tagged plant, and considered the mean of these counts for

190 each population as one component of average realized fecundity. Mean seeds per flower in

191 the OP treatment served as another component, and when multiplied by the average estimate

192 of flowers per plant for each population yielded a final component, the estimated mean total

193 seeds per plant for that population.

194

195 2.6. Data analysis

196

197 Some populations were destroyed or damaged before the study was completed; for these we

198 analyzed only data collected before destruction (populations 11, 16, 24; Table 1) or from

199 plants that escaped damage (populations 3, 7, 17). Seed set in GR population 11 was low

200 even after pollen was added by hand. Because GR populations tend to be self-incompatible

201 (Petanidou et al. 2012) this suggests low genetic diversity, and preliminary investigation 
supports this hypothesis (R. Kariyat et al. unpublished). We excluded GR population 11 from analyses of seed and fruit set and PLI, but included its fecundity values in Table 2 and figures.

Our AZ and GR populations are samples from those geographic areas. In this sense the differences attributed to "country" in analyses cannot be taken to represent Arizona (or the USA) vs. Greece overall, nor the overall ancestral vs. invaded ranges. Nonetheless it is legitimate to compare how aspects of investment in female sexual function (i.e., flowers and ovules), pollination, and fecundity varied in our samples with population size score and type of disturbance, using ANOVA or ANCOVA. When multiple independent variables could be expected a priori to contribute to variation in a response variable, we took a model-selection approached based on minimizing AICc. Imbalance in our sample of AZ and GR populations did not permit estimation of country $\times$ population size $\times$ disturbance interactions. For wholeplant traits we included plant height as a covariate, since total flower, ovule, and fruit production generally scale with plant stature, and AZ and GR samples might differ in scaling relationships. For per-flower fecundity variables, we included pollinator visit rate and ovule number as covariates. To help evaluate any apparent nonlinear relationships between reproductive variables and population size we treated population size score as a continuous variable and included second-order as well as first-order terms. With the exception of plant height, analyses were based on grand means for populations, because we rarely obtained multiple values per plant for other measured variables, so that plants nested within populations served as the error term. In any event we are concerned here first and foremost with patterns of variation among populations. For plant height, we could use plants nested within populations as the error term and treat population nested within country as a random effect. We transformed variables as needed to normalize model residuals. All analyses were 
implemented in JMP Pro 11 (SAS Institute, Cary, North Carolina, USA). Table S1 summarizes models and variable transformations used in analyses.

\section{Results}

\subsection{Investment in flowers and ovules}

In our AZ sample mean plant height increased from small to medium-sized to large populations $(43.4 \mathrm{~cm}, 62.0 \mathrm{~cm}, 71.2 \mathrm{~cm}$, respectively), whereas no such pattern appeared in GR populations $\left(67.6 \mathrm{~cm}, 66.8 \mathrm{~cm}, 64.7 \mathrm{~cm}\right.$, respectively; Fig. $1 ; \mathrm{F}_{1,19.17}=4.252, \mathrm{P}=0.053$ for the interaction between country and population size from ANOVA using ln-transformed height values). Similarly, tilled AZ populations supported taller plants on average than did populations experiencing surface disturbance $(67.8 \mathrm{~cm}$ and $43.4 \mathrm{~cm}$, respectively), whereas this was not true in GR populations $\left(65.1 \mathrm{~cm}\right.$ and $65.4 \mathrm{~cm}$, respectively; $\mathrm{F}_{1,19.14}=4.664, \mathrm{P}=$ 0.044 for the interaction between country and disturbance type).

Estimated mean total flower production per plant was positively related to plant height $\left(\mathrm{F}_{1,18}=10.077, \mathrm{P}=0.005\right.$ from ANOVA with ln-transformed values of flowers per plant). The slope of this relationship was not obviously different for AZ and GR populations (Fig. $2 ; \mathrm{F}_{1,18}=0.251, \mathrm{P}=0.623$ for the interaction between country and height). Because AZ plants were smaller on average than GR plants, their estimated total flower production also appeared somewhat smaller (mean $\pm \mathrm{SE}[\mathrm{N}]: 309.5 \pm$ 111.62 flowers [8] vs. $403.0 \pm 89.11$ flowers [14]). 
250 Ovule number is a more precise proxy than flower number for initial female

251 investment. In both AZ and GR populations ovule number per flower increased

252 nonlinearly to an apparent plateau with increasing population size (positive linear and

253 negative second-order effects from polynomial ANCOVA with ln-transformed values

254 of ovules per flower), but the plateau was somewhat lower in AZ than in GR

255 populations (Fig. $3 ; \mathrm{F}_{1,17}=4.666, \mathrm{P}=0.045$ for the interaction between country and

256 population size). Plant height had a slight negative effect because several small

257 populations had tall plants that produced flowers with few ovules (compare Figs.1, 3).

258 Overall, AZ plants allocated fewer ovules per flower than GR plants (mean $\pm \mathrm{SE}[\mathrm{N}]$ :

$25955.3 \pm 4.66$ ovules [9] vs. $\left.95.3 \pm 5.75[19] ; F_{1,17}=102.488, P<0.0001\right)$. Since GR

260 plants produced more flowers, they also allocated more to ovules on a per-plant basis.

262 3.2. Pollinator visits and pollination success

264 Flowers in all AZ populations and GR populations on Lesvos attracted up to six

265 species of buzz-pollinating bees (Table 3). AZ and GR populations shared no species

266 in common, but their bees belonged to equivalent functional groups and often to the

267 same genera (e.g., Xylocopa and Bombus, Apidae; Nomia and Pseudapis, Halictidae).

268 Several other insects, mainly small sweat bees (e.g., Halictus resurgens, Halictidae),

269 honeybees (Apis mellifera), and rarely small bees of the genus Megachile, visited

270 flowers on Lesvos without buzzing, collecting pollen that was shed on the surface of

271 anthers and the corolla after flowers were buzzed by other bees or shaken by winds

272 (see Section 4.2). We assumed that non-buzzers did not release new pollen from

273 anthers and had little impact on seed set, and so ignored them in visit rate estimates. 
275 Observed rates of flower visits by buzzing pollinators decreased nonlinearly with

276 population size overall (Fig. $4 ; \mathrm{F}_{1,21}=2.664, \mathrm{P}=0.118$ and $\mathrm{F}_{1,21}=13.507, \mathrm{P}=0.0014$,

277 respectively, from polynomial ANCOVA for first and second-order effects on square-

278 root transformed values of visit rate). The decrease was less pronounced in AZ than

279 GR populations $\left(\mathrm{F}_{1,21}=17.283, \mathrm{P}=0.0004\right.$ for the interaction between country and

280 population size), but there was no clear difference in visit rates between AZ and GR

281 (mean $\pm \mathrm{SE}[\mathrm{N}]: 0.070 \pm 0.084$ visits per flower per hour [9] vs. $0.113 \pm 0.061[17]$

$\left.282 \mathrm{~F}_{1,21}=1.70, \mathrm{P}=0.685\right)$. In the smallest populations, mean visit rates remained below

283 one per flower per hour, except for GR population 10 on Lesvos (Table 2). In the 13

284 large GR populations near Thessaloniki (13, 14, 16-18, 20-27) we observed no visits

285 at all, whereas this was not the case in the largest AZ population 7 (Table 2).

286

287 PLI provides one gauge of the effectiveness of pollination; indeed it decreased overall

288 with pollinator visit rate (Fig. $5 ; \mathrm{F}_{1,21}=5.352, \mathrm{P}=0.031$ from ANCOVA using

289 square-root-transformed values of visit rate) in a similar fashion in populations from

$290 \mathrm{AZ}$ and $\mathrm{GR}\left(\mathrm{F}_{1,21}=0.341, \mathrm{P}=0.566\right.$ for the interaction between country and visit

291 rate). Overall, PLI was lower in our AZ than GR populations (mean $\pm \mathrm{SE}[\mathrm{N}]: 0.447$

$292 \pm 0.090[9]$ vs. $\left.0.878 \pm 0.063[17] ; \mathrm{F}_{1,21}=10.865, \mathrm{P}=0.0034\right)$, but there was

293 considerable scatter, with some GR populations (notably 10) having high PLI in spite

294 of high visit rates, and others having lower visit rates but low PLI.

296 3.3. Fruit and seed set

298 Initial investment in flowers and ovules is expected to contribute to components of

299 realized fecundity such as fruit and seed set. Indeed, of alternative models including 
$\ln$ (plant height), country, and pollinator visit rate, the best model indicated that total

301 number of fruits produced by a plant was positively related to plant height $\left(\mathrm{F}_{1,17}=\right.$

$30211.211, \mathrm{P}=0.004$ from ANOVA using ln-transformed values of fruits per plant), a

303 relationship that did not obviously differ between AZ and GR populations (Fig. 6;

$304 \mathrm{~F}_{1,17}=0.808, \mathrm{P}=0.381$ for the interaction between country and height). This result

305 seems logical given that flower number increases with plant height (see Section 3.1).

306 Nonetheless, even though AZ plants were on average slightly smaller than GR plants,

307 fruit production was higher in AZ than GR populations (mean fruits per plant $\pm \mathrm{SE}$

$308[\mathrm{~N}]: 80.400 \pm 17.196[9]$ vs. $\left.38.914 \pm 13.490[16] ; \mathrm{F}_{1,17}=12.243, \mathrm{P}=0.0027\right)$.

309 Inferior pollination service in GR populations may have contributed to lower

310 fecundity. Whereas pollinator visit rate was excluded from the best model described

311 above (perhaps because it was an imperfect predictor of pollen limitation), the best

312 model when we included PLI as a predictor of total fruits per plant chose PLI, ln

313 (height), and PLI $\times \ln ($ height), but excluded country. In this alternative model, $\ln$

314 (fruits per plant) increased with $\ln$ (height) as before $\left(\mathrm{F}_{1,17}=9.026, \mathrm{P}=0.008\right)$ and

315 decreased with PLI $\left(\mathrm{F}_{1,17}=14.008 \mathrm{P}=0.0016\right)$. There was no indication that PLI

316 interacted with plant height.

318 Although per-plant fruit production was more strongly related to PLI than to visit rate,

319 the best-fit model for the number of seeds produced per marked, open-pollinated

320 flower did include visit rate in addition to country. Mean seeds per flower increased

321 with visit rate (Fig. 7; $\mathrm{F}_{1,21}=4.479, \mathrm{P}=0.046$ from ANCOVA using square-root-

322 transformed values for seeds per flower), and the increase was similar in AZ and GR

323 populations $\left(\mathrm{F}_{1,21}=0.012, \mathrm{P}=0.914\right.$ for the interaction between country and visit

324 rate). Open-pollinated flowers (OP treatment) in AZ populations produced more 
325 seeds than those in GR populations (mean seeds per flower $\pm \mathrm{SE}[\mathrm{N}]: 13.611 \pm 4.568$

326 [9] vs. $\left.4.888 \pm 2.964[16] ; \mathrm{F}_{1,21}=2.605, \mathrm{P}=0.121\right)$. In contrast, flowers that had

327 received pollen by hand from distant donors in addition to open pollination (PA

328 treatment) showed the opposite pattern. Those in AZ populations produced fewer

329 seeds than those in GR populations (22.433 \pm 6.872 [9] vs. $53.569 \pm 4.706[16])$, as

330 expected if one considers only mean differences in numbers of ovules per flower (see

331 Section 3.1).

332

333 4. Discussion

334

335 This study was designed to compare aspects of reproduction of S. elaeagnifolium in replicate

336 populations within and outside of the ancestral range, in order to shed light on factors that

337 may affect invasion by this species. In what follows we first consider each aspect of

338 reproduction and pollination that we studied, then conclude with implications for future

339 studies.

340

341 4.1. Investment in flowers and ovules

342

343 Our GR populations allocated more than our AZ populations to female sexual function (i.e., to

344 flowers and ovules). Whereas plant stature in AZ populations increased in larger populations

345 and with deeper soil disturbance, this was not evident for GR populations, where plants

346 tended to be as tall as the tallest AZ plants. As a result, GR plants were taller on average, and

347 produced more flowers. They also allocated on average nearly twice as many ovules to each

348 flower.

349 
350 Williams et al. (2016) documented evolution of increased plant stature across only 6

351 generations in a mesocosm invasion experiment. The tenure of S. elaeagnifolium in Greece

352 might suffice for similar changes, driven by a positive correlation of height and seed dispersal

353 distance (as Williams et al. 2016 speculate for their system) or by selection for greater flower

354 number. Burd (1995) presented a model that predicts that increased ovule number per flower

355 can be selected when pollination service is more variable. In this context, greater allocation to

356 flowers and ovules in GR populations might represent a "bet-hedging" response to greater

357 variation in the Greek pollination environment.

359 4.2. Pollinator visits and pollination success

361 Plants experienced high visit rates and good pollination success in some Greek populations, 362 such as those on Lesvos, due to the attention of native bees that resemble those in Arizona. 363 Both AZ and GR populations also hosted similar guilds of non-buzzing flower visitors. Thus 364 S. elaeagnifolium is successfully incorporated into networks of plant-pollinator interactions 365 that lack its ancestral pollinators (see also Memmott and Waser 2002; Stout et al. 2006; 366 Kaiser-Bunbury et al. 2009; Vilà et al. 2009). But pollination was far from assured in GR 367 populations, especially those around Thessaloniki, even though Greece is considered a "bee 368 paradise" (Petanidou and Ellis 1993, 1996; Petanidou and Lamborn 2005; Nielsen et al.

369 2011). Use of agricultural chemicals, habitat loss, and industrial development may contribute 370 to bee rarity around Thessaloniki, and frequent tilling may exclude ground-nesting bees (see 371 also Williams and Kremen 2007). Due to limited flight range (Greenleaf et al. 2007), many 372 bees cannot add large monospecific stands to a foraging itinerary that requires access to water 373 and a progression of flowers sufficient for a complete life cycle. Thessaloniki exemplifies 
374 what we term an invasive desert - a monospecific stand that supports strikingly low

375 ecological diversity (see Fig. S1).

376

377 Although we recorded no buzzing pollinators in most Thessaloniki populations, flowers did 378 set some seeds. Without vibration, it is difficult to extract pollen from the anthers of $S$.

379 elaeagnifolium, but it remains possible that pollen grains are small enough $(<30 \mu \mathrm{m}$; Luna-

380 Cavazos and García-Moya 2002; Burkart et al. 2014) to be shaken out by local "etesian"

381 winds on hot summer days. The presence of such pollen might explain visits by honey bees

382 and other non-buzzing bees, which might cause some seed set, as appears to happen with

383 hover flies visiting (and not buzzing) Solanum dulcamara (Waser et al. 2011). If this

384 unexpected pollination occurs but is highly variable, its variation might contribute to greater

385 sexual allocation by the bet-hedging mechanism discussed above.

387 4.3. Fruit and seed set

389 Although GR plants produced more flowers and ovules than AZ plants, they did not achieve 390 greater fecundity in terms of fruit or seed set. This was true especially in large monospecific 391 stands, which had large PLI values. These results suggest that GR populations received 392 poorer pollination service, and perhaps also pollen of poorer "quality" (sensu Waser and Price 393 1983, p. 356; Aizen and Harder 2007). GR plants are less self-compatible than those in our 394 AZ populations (see Petanidou et al. 2012). Thus the availability of genetically-compatible 395 pollen donors may be lower, especially if some populations are formed by extensive 396 vegetative spread through rhizomes. We excluded one GR population from analyses because 397 we suspected that low genetic variability caused pollen-supplemented flowers to have very 398 low fecundity (see Section 2.6). 
400 4.4. Implications for future studies

401

402 Our results suggest that increased investment in female sexual function accompanies

403 dispersal of S. elaeagnifolium beyond the ancestral range as well as transition from

404 small ruderal populations mixed with other species to large monospecific populations.

405 This greater investment occurs in concert with reduced self-compatibility (Petanidou

406 et al. 2012), and does not yield higher realized fecundity, at least in large GR

407 populations, perhaps because such environments are unfavorable for pollinators and

408 compatible mates are few.

409

410 Nonetheless, S. elaeagnifolium is obviously successful as an invasive. Its aggressive spread

411 appears to be favored by the same conditions in AZ and GR populations: deep soil

412 disturbance over large areas, which may facilitate spread by rhizome fragments. While this

413 does suggest some opportunities for control, such as replacement of tilling by mowing, many

414 questions remain for further study.

415

416 For closer comparison with Greece, a priority is to extend the study of pollination and

417 reproduction to additional populations in more Mediterranean climates within the ancestral

418 range, as opposed to the desert climates of Arizona. The species is found in Mediterranean-

419 climate southern California (Munz 1974), South Africa (Boyd et al. 1984), and Australia (Zhu

420 et al. 2013). Additional observations of pollinator visits in the largest GR populations (and

421 elsewhere) also would be useful, in part to document temporal variation. Also valuable would

422 be further investigation of the possibility of pollination via wind and non-buzzing visitors. 
424 We have noted that low seed set and high PLI might be influenced by paucity of compatible

425 pollen even if pollinator visits are common. In our experimental pollen additions we chose

426 donors 5-20 $\mathrm{m}$ from recipient flowers. Perhaps on this spatial scale plant ramets usually

427 belong to different genetic individuals, whereas at shorter scales, over which pollinators

428 transfer most pollen in dense populations (Waser 1982), ramets often belong to the same

429 genet and so mates tend to be incompatible. This could be explored using genetic analysis to

430 characterize the spatial extent of clonal spread via rhizomes in populations of different sizes

431 and disturbance regimes (see Ellstrand and Roose 1987).

433 Our emphasis on sexual reproduction and aboveground allocation leaves unanswered 434 questions about belowground allocation to rhizomes. Analysis of the extent of individual 435 genets might be combined with measures of vegetative spread via rhizomes in populations 436 with different characteristics. In a preliminary study (R. Kariyat et al. unpublished), seeds 437 performed poorly in many respects (e.g., in plant establishment) compared to rhizome pieces 438 collected from the same plants in large Thessaloniki populations. Space filling by rhizomes 439 (along with seeds) may occur in tilled agricultural lands, where S. elaeagnifolium is 440 remarkably successful; seeds also might allow rapid colonization of new suitable habitat 441 fragments (see Williams et al. 2016).

443 Finally, any differences in the expression of sexual characteristics of $S$.

444 elaeagnifolium plants documented here, as functions of population size, disturbance

445 regime, and country, might logically represent adaptive or neutral genetic differences

446 that trace back to those individuals that founded Greek populations and those in

447 Arizona landscapes that have been recently altered. Founder effects can be detected

448 through reduced genetic diversity at neutral or quasi-neutral marker loci (Dlugosch 
and Parker 2008). Alternatively, any differences in character expression might represent adaptations arising during decades of habitation in Greece or in altered Arizona landscapes. Finally, they might be plastic responses to local conditions (Zhu et al. 2013). The classic approach (Langlet 1971) to distinguishing genetic and plastic mechanisms of phenotypic differentiation is to grow plants in common gardens, and to do this reciprocally between ancestral and invaded ranges.

\section{Conflict of interest}

The authors state that they have no conflict of interest.

\section{Acknowledgements}

TP was supported in Arizona by a Fulbright Foundation award and in Greece by the European Commission Framework Programme 6 (Integrated Project ALARM; GOCE-CT-2003506675). We thank S. Allen, A. Huynh, C. Zografou, M. Ntikoliakou, K. Georghiou, C. Alexiou, A. Karatza, M. Williams, G. Davidowitz, N. Kantsas and R. Alarcón for assistance in field or laboratory. TP thanks the Santa Rita Experimental Range for permitting fieldwork, J. Ascher for insect identification, and S. Buchmann and R. Thorp for stimulating discussions and information on silverleaf nightshade populations in Arizona.

\section{References}

Aizen, MA, Harder LD (2007) Expanding the limits of the pollen-limitation concept: effects of pollen quantity and quality. Ecology 88:271-281. DOI: 10.1890/061017 
Atlan A, Schermann-Legionnet A, Udo N, Tarayre M (2015) Self-incompatibility in Ulex europaeus: variations in native and invaded regions. International Journal of Plant Sciences 176:515-524

Baker DC, Keeler RF, Gaffield W (1989) Pathology in hamsters administered Solanum plant species that contain steroidal alkaloids. Toxicon 27:1331-1337. DOI: $10.1016 / 0041-0101(89) 90065-2$

Barrett SC (2011) Why reproductive systems matter for the invasion biology of plants? In: Richardson DM (ed) Fifty years of invasion ecology: the legacy of Charles Elton.John Wiley \& Sons, New York, pp 195-210.

Boyd JW, Murray DS, Tyrl RJ (1984) Silverleaf nightshade, Solanum elaeagnifolium, origin, distribution, and relation to man. Economic Botany 38:210-217

Brunel, S, Brundu G, Fried G (2013) Eradication and control of invasive alien plants in the mediterranean basin: towards better coordination to enhance existing initiatives. EPPO Bulletin, 43:290-308

Buchmann SL, Cane JH (1989) Bees assess pollen returns while sonicating Solanum flowers. Oecologia 81:289-294

Burd M (1995) Ovule packaging in stochastic pollination and fertilization environments. Evolution 49:100-109

Burkart A, Schlindwein C, Lunau K (2014) Assessment of pollen reward and pollen availability in Solanum stramoniifolium and Solanum paniculatum for buzzpollinating carpenter bees. Plant Biology 16:503-507

Caño L, Escarre J, Fleck I, Blanco-Moreno JM, Sans FX (2008) Increased fitness and plasticity of an invasive species in its introduced range: a study using Senecio pterophorus. Journal of Ecology 96:468-476. DOI: 10.1111/j.13652745.2008.01363.x 
499 Colautti RI, Barrett SCH (2011). Population divergence along lines of genetic

500 variance and covariance in the invasive plant Lythrum salicaria in eastern

$501 \quad$ North America. Evolution 65:2514-2529. DOI:10.1111/j.1558-

$502 \quad 5646.2011 .01313 . x$

503 Cooley AW, Smith DT (1971) Silverleaf nightshade (whiteweed) establishment from

504 seed and clipped seedlings. Progress Report of Texas A\&M University, Texas

$505 \quad$ Agricultural Experiment Station PR-3198

506 De Los Santos GG, Steiner JJ, Beuselinck PR (2001) Adaptive ecology of Lotus

507 corniculatus L. genotypes: II. Crossing ability. Crop Science, 41:564-570

508 Dlugosch KM, Parker IM (2008) Founding events in species invasions: genetic

509 variation, adaptive evolution, and the role of multiple introductions. Molecular

510 Ecology 17: 431-449. DOI:10.1111/j.1365-294X.2007.03538.x

511 Ellstrand NC, Roose ML (1987) Patterns of genotypic diversity in clonal plant

$512 \quad$ species. American Journal of Botany 74:123-131

513 Elton CS (1958) The ecology of invasions by animals and plants. Methuen, London

514 Greenleaf SS, Williams NM, Winfree R, Kremen C (2007) Bee foraging ranges and

515 their relationship to body size. Oecologia 153:589-596. DOI:

$516 \quad 10.1007 / \mathrm{s} 00442-007-0752-9$

517 Kaiser-Bunbury CN, Memmott J, Müller CB (2009) Community structure of

518 pollination webs of Mauritian heathland habitats. Perspectives in Plant

519 Ecology, Evolution, and Systematics 11:241-254. DOI:

$520 \quad 10.1016 /$ j.ppees.2009.04.001

521 Kearney TH, Peebles RH, Howell JT, et al. (1969) Arizona flora, second edition.

$522 \quad$ University of California Press, Berkeley 
523 Keeler RF, Baker DC, Gaffield W (1990) Spirosolane-containing Solanum species

524 and Induction of congenital craniofacial malformations. Toxicon 28:873-884.

525 DOI: $10.1016 / 0041-0101(90) 90017-2$

526 Krigas N, Kokkini S (2004) A survey of the alien vascular flora of the urban and

527 suburban area of Thessaloniki, N Greece. Willdenowia 34:81-99.

$528 \quad$ DOI: $10.3372 /$ wi.34.34108

529 Lafuma L, Maurice S (2007) Increase in mate availability without loss of self-

530 incompatibility in the invasive species Senecio inaequidens (Asteraceae).

$531 \quad$ Oikos 116:201-208. DOI: 10.1111/j.2006.0030-1299.15220.x

532 Langlet O (1971) Two hundred years genecology. Taxon 20: 653-721

533 Li X-M, Liao W-J, Wolfe LM, Zhang D-Y (2012) No evolutionary shift in the mating

534 system of North American Ambrosia artemisiifolia (Asteraceae) following its

$535 \quad$ introduction to China. PLoS ONE 7(2):e31935.

536 DOI:10.1371/journal.pone.0031935

537 Luna-Cavazos M, García-Moya E (2002) Morphological and pollen differentiation in

538 Solanum cardiophyllum ssp. cardiophyllum and S. cardiophyllum ssp.

539 ehrenbergii. Botanical Journal of the Linnean Society 140:415-426

540 Mandák B, Zákravský P, Kořínková D, Dostál P, Plačková I (2009) Low population

541 differentiation and high genetic diversity in the invasive species Carduus

542 acanthoides L. (Asteraceae) within its native range in the Czech Republic.

543 Biological Journal of the Linnean Society 98:596-607. DOI: $10.1111 / \mathrm{j} .1095-$

$544 \quad 8312.2009 .01304 . x$

545 Mekki M (2007) Biology, distribution and impacts of silverleaf nightshade (Solanum

546 elaeagnifolium Cav.). EPPO Bulletin 37:114-118 
547 Memmott J, Waser NM (2002) Integration of alien plants into a native flower-

548 pollinator visitation web. Proceedings of the Royal Society B 269:2395-2399.

$549 \quad$ DOI: $10.1098 / \mathrm{rspb} .2002 .2174$

550 Montero-Castaño A, Vilà M, Ortiz-Sánchez FJ (2014). Pollination ecology of a plant

551 in its native and introduced areas. Acta Oecologica 56:1-9. DOI:

$552 \quad 0.1016 /$ j.actao.2014.01.001

553 Munz PA (1974) Flora of Southern California. University of California Press, $554 \quad$ Berkeley

555 Nielsen A, Steffan-Dewenter I, Westphal C, Vaitis M, Woyciechowski M, Bazos I, 556 Biesmeijer JC, Bommarco R, Kunin WE, Lamborn E, Messinger O, Potts SG, 557 Roberts S, Szentgyorgyi H, Settele J, Vaissiere BE, Petanidou T (2011)

558 Assessing bee species richness in two Mediterranean communities: importance 559 of habitat type and sampling techniques. Ecol Res 26:969-983. DOI:

$560 \quad 10.1007 / \mathrm{s} 11284-011-0852-1$

561 Petanidou T, Ellis WN (1993) Pollinating fauna of a phryganic ecosystem:

562 composition and diversity. Biodiversity Letters 1:9-22

563 Petanidou T, Ellis WN (1996) Interdependence of native bee faunas and floras in 564 changing Mediterranean communities. The conservation of bees. The Linnean 565 Society of London and the International Bee Research Association

566 Petanidou T, Godfree RC, Song DS, Kantsa A, Dupont YL, Waser NM (2012) Self-

567 compatibility and plant invasiveness: comparing species in native and invasive $568 \quad$ ranges. Perspect Plant Ecol Evol Syst 14:3-12. DOI:

$569 \quad 10.1016 /$ j.ppees.2011.08.003

570 Petanidou T, Lamborn E (2005) A land for flowers and bees: studying pollination 571 ecology in Mediterranean communities. Plant Biosystems 139:279-294 
572 Petanidou T., Ståhls G., Vujić A., Olesen J.M., Rojo S., Thrasyvoulou A., Sgardelis S., 573 Kallimanis A.S., Kokkini S., Tscheulin T. (2013). Investigating plant574 pollinator relationships in the Aegean: the approaches of the project POL575 AEGIS (The Pollinators of the Aegean Archipelago: Diversity and Threats). $576 \quad$ Journal of Apicultural Research 52:106-117. 577 http://dx.doi.org/10.3896/IBRA.1.52.2.20

578 Pimentel D, McNair S, Janecka J, Wightman J, Simmonds C, O'Connell C, Wong 579 E, Russel L, Zern J, Aquino, T, Tsomondo T (2001) Economic and 580 environmental threats of alien plant, animal, and microbe invasions. $581 \quad$ Agriculture, Ecosystems and Environment 84:1-20

582 Richardson DM, Pysek P (2006) Plant invasions: merging the concepts of species 583 invasiveness and community invasibility. Progress in Physical Geography 584 30:409-431. DOI: 10.1191/0309133306pp490pr

585 Stout JC, Parnell JAN, Arroyo J, Crowe TP (2006) Pollination ecology and seed 586 production of Rhododendron ponticum in native and exotic habitats.

587 Biodiversity and Conservation 15:755-777. DOI: 10.1111/j.1365$588 \quad 2745.2008 .01363 . x$

589 Tanentzap AJ, Bazely DR, Lafortezza R (2010) Diversity-invasibility relationships 590 across multiple scales in disturbed forest understoreys. Biological Invasions 591 12:2105-2116. DOI: 10.1007/s10530-009-9612-3

592 Traveset A, Richardson DM (2006) Biological invasions as disruptors of plant 593 reproductive mutualisms. Trends in Ecology and Evolution 21:208-216

594 Tscheulin T, Petanidou T (2013) The presence of the invasive plant Solanum 595 elaeagnifolium deters honeybees and increases pollen limitation in the native 
co-flowering species Glaucium flavum. Biological Invasions 15:385-393. DOI: $10.1007 / \mathrm{s} 10530-012-0293-\mathrm{y}$

598 Tscheulin T, Petanidou T, Potts SG, Settele J (2009) The impact of Solanum elaeagnifolium, an invasive plant in the Mediterranean, on the flower Database. National Plant Data Center, Baton Rouge, http://plants.usda.gov

van Kleunen M, Weber E, Fischer M (2010) A meta-analysis of trait differences between invasive and non-invasive plant species. Ecology Letters 13:235-245. DOI: $10.1111 /$ j.1461-0248.2009.01418.x

Vilà M, Bartomeus I, Dietzsch AC, Petanidou T, Steffan-Dewenter I, Stout JC, Tscheulin T (2009) Invasive plant integration into native plant-pollinator networks across Europe. Proceedings of the Royal Society B 276:3887-3893. DOI: $10.1098 /$ rspb.2009.1076

Waser NM (1982) A comparison of distances flown by different visitors to flowers of the same species. Oecologia 55:251-257. DOI: 10.1007/BF00384496

Waser NM, Ollerton J, Erhardt A (2011) Typology in pollination biology: lessons from an historical critique. Journal of Pollination Ecology $3: 1-7$ 
619 Waser NM, Price MV (1983) Optimal and actual outcrossing in plants, and the nature

620 of plant-pollinator interaction. In Jones CE, Little RE (eds) Handbook of

621 Experimental Pollination Biology. Van Nostrand Reinhold, New York, pp

$622 \quad 341-359$

623 Williams, JL, Kendall BE, Levine JM (2016) Rapid evolution accelerates plant

624 population spread in fragmented experimental landscapes. Science 353:482-

625 484. DOI: $10.1126 /$ science.aaf6268

626 Williams NM, Kremen C (2007) Resource distributions among habitats determine

627 solitary bee offspring production in a mosaic landscape. Ecological

628 Applications 17:910-921. DOI: 10.1890/06-0269

629 Zhu XC, Wu HW, Stanton R, Burrows GE, Lemerle D, Raman H (2013)

630 Morphological variation of Solanum elaeagnifolium in south-eastern Australia.

$631 \quad$ Weed Research 53:344-354

632

633

634

635 TP designed the study with input from NW. TP and AK carried out fieldwork. MP and TT

636 analysed the data. TP, NW, and MP wrote the manuscript. All authors edited the manuscript. 
Table 1. Solanum elaeagnifolium populations studied in Arizona (ancestral range) and Greece (invaded range). Criteria for evaluating type of disturbance and population size score are described in the text. Dates of observation of pollinators and of hand pollination to assess pollen limitation are given as days/month/year.

\begin{tabular}{|c|c|c|c|c|c|c|c|}
\hline Population & Region & Coordinates & Habitat characteristics & Disturbance & $\begin{array}{l}\begin{array}{l}\text { Size } \\
\text { (\# of plants) }\end{array} \\
\end{array}$ & $\begin{array}{l}\text { Size } \\
\text { score }\end{array}$ & $\begin{array}{l}\text { Dates of observation } \\
\text { and hand pollination }\end{array}$ \\
\hline \multicolumn{8}{|l|}{ Arizona } \\
\hline 1. Marana, Kai cotton & Pima & $32^{\circ} 26^{\prime} 50^{\prime \prime} \mathrm{N}, 111^{\circ} 18^{\prime} 12^{\prime \prime} \mathrm{W}$ & within intensely cultivated cotton field & tilled & ca. 800 & 0 & $22-23,25 / 07 / 2006$ \\
\hline 2. Marana, Kai fallow & Pima & $32^{\circ} 26^{\prime} 55^{\prime \prime} \mathrm{N}, 111^{\circ} 18^{\prime} 13^{\prime \prime} \mathrm{W}$ & paved road verge & surface & $>2000$ & 1 & $22-23,25 / 07 / 2006$ \\
\hline 3. Marana, Sanders cotton & Pima & $32^{\circ} 26^{\prime} 45^{\prime \prime} \mathrm{N}, 111^{\circ} 14^{\prime} 40^{\prime \prime} \mathrm{W}$ & unpaved road verge & surface & $>2000$ & 1 & $22-23,25 / 07 / 2006$ \\
\hline 4. Marana, Sanders fallow & Pima & $32^{\circ} 28^{\prime} 03^{\prime \prime} \mathrm{N}, 111^{\circ} 14^{\prime} 03^{\prime \prime} \mathrm{W}$ & margins of intensely cultivated field & tilled & $>2000$ & 1 & $22-23,25 / 07 / 2006$ \\
\hline 5. Santa Rita, lower & Pima & $31^{\circ} 46^{\prime} 48 \mathrm{~N}, 110^{\circ} 53^{\prime} 16^{\prime \prime} \mathrm{W}$ & paved road verge in a conservation area & surface & ca. 100 & 0 & $18-19 / 07 / 2006$ \\
\hline 6. Santa Rita, upper & Pima & $31^{\circ} 46^{\prime} 12^{\prime \prime} \mathrm{N}, 110^{\circ} 53^{\prime} 15^{\prime \prime} \mathrm{W}$ & paved road verge in a conservation area & surface & ca. 500 & 0 & $18-19 / 07 / 2006$ \\
\hline 7. San Simon, huge & Cochise & $32^{\circ} 15^{\prime} 05^{\prime \prime} \mathrm{N}, 109^{\circ} 11^{\prime} 10^{\prime \prime} \mathrm{W}$ & entire surface of a fallow field & tilled & $>10,000$ & 2 & $05-06 / 08 / 2006$ \\
\hline 8. San Simon, Noland & Cochise & $32^{\circ} 15^{\prime} 19^{\prime \prime} \mathrm{N}, 109^{\circ} 10^{\prime} 35^{\prime \prime} \mathrm{W}$ & margins of intensely cultivated field & tilled & $>2000$ & 1 & $05-06 / 08 / 2006$ \\
\hline $\begin{array}{l}\text { 9. Willcox, Moonlight } \\
\text { Greece }\end{array}$ & Cochise & $32^{\circ} 14^{\prime} 19^{\prime \prime} \mathrm{N}, 109^{\circ} 46^{\prime} 41^{\prime \prime} \mathrm{W}$ & unpaved road verge; wild & surface & ca. 800 & 0 & $26 / 08 / 2006$ \\
\hline 10. Arisvi & Lesvos & $39^{\circ} 14^{\prime} 08^{\prime \prime} \mathrm{N}, 26^{\circ} 13^{\prime} 31^{\prime \prime} \mathrm{E}$ & unpaved road verge; naturalized & surface & ca. 1500 & 0 & $4-5 / 07 / 2014$ \\
\hline 11. Eressos & Lesvos & $39^{\circ} 08^{\prime} 24^{\prime \prime} \mathrm{N}, 25^{\circ} 55^{\prime} 19^{\prime \prime} \mathrm{E}$ & residential lawn; naturalized & surface & ca. 150 & 0 & $13 / 08 / 2006$ \\
\hline 12. Plomari & Lesvos & $38^{\circ} 58^{\prime} 17^{\prime} ’ \mathrm{~N}, 26^{\circ} 22^{\prime} 57^{\prime \prime} \mathrm{E}$ & paved road verge; naturalized & surface & ca. 100 & 0 & $7-8 / 07 / 2014$ \\
\hline 13. Anchialos, Cemetery & Thessaloniki & $40^{\circ} 43^{\prime} 05^{\prime} \mathrm{N}, 22^{\circ} 47^{\prime} 07^{\prime \prime} \mathrm{E}$ & dry waste land & surface & $>10,000$ & 2 & $24 / 07 / 2007$ \\
\hline 14. Anchialos, Farmakis & Thessaloniki & $40^{\circ} 43^{\prime} 25^{\prime \prime} \mathrm{N}, 22^{\circ} 48^{\prime} 31^{\prime \prime} \mathrm{E}$ & cultivated field (barley, vetch) & tilled & $>10,000$ & 2 & 01/08/2007 \\
\hline 15. Anchialos, Ioannou & Thessaloniki & $40^{\circ} 42^{\prime} 19^{\prime \prime} \mathrm{N}, 22^{\circ} 47^{\prime} 18^{\prime \prime} \mathrm{E}$ & waste land/yard of a factory & surface & $>2000$ & 1 & $31 / 07 / 2007$ \\
\hline 16. Anchialos, Narlis & Thessaloniki & $40^{\circ} 43^{\prime} 34^{\prime \prime} \mathrm{N}, 22^{\circ} 47^{\prime} 57^{\prime \prime} \mathrm{E}$ & cultivated field (barley, vetch) & tilled & $>10,000$ & 2 & $02 / 08 / 2007$ \\
\hline 17. Anchialos, Toumba & Thessaloniki & $40^{\circ} 43^{\prime} 07^{\prime \prime} \mathrm{N}, 22^{\circ} 49^{\prime} 05^{\prime \prime} \mathrm{E}$ & waste land & surface & $>10,000$ & 2 & 02/08/2007 \\
\hline 18. Anchialos, Vaggelis & Thessaloniki & $40^{\circ} 43^{\prime} 40^{\prime \prime} \mathrm{N}, 22^{\circ} 48^{\prime} 28^{\prime \prime} \mathrm{E}$ & wheat field left fallow & tilled & $>10,000$ & 2 & 03/08/2007 \\
\hline 19. Panorama & Thessaloniki & $40^{\circ} 35^{\prime} 22^{\prime \prime} \mathrm{N}, 23^{\circ} 02^{\prime} 38^{\prime \prime} \mathrm{E}$ & semi-natural meadow in urbanized area & surface & $>2000$ & 1 & $04,11 / 08 / 07$ \\
\hline 20. Raidestos, Atlanta & Thessaloniki & $40^{\circ} 32^{\prime} 14^{\prime \prime} \mathrm{N}, 23^{\circ} 02^{\prime} 49^{\prime \prime} \mathrm{E}$ & wheat field & tilled & $>10,000$ & 2 & $13 / 07 / 2007$ \\
\hline 21. Raidestos, onion & Thessaloniki & $40^{\circ} 31^{\prime} 05^{\prime \prime} \mathrm{N}, 23^{\circ} 03^{\prime} 23^{\prime \prime} \mathrm{E}$ & onion field & tilled & $>10,000$ & 2 & $30 / 07 / 2007$ \\
\hline 22. Raidestos, wheat & Thessaloniki & $40^{\circ} 30^{\prime} 59^{\prime \prime} \mathrm{N}, 23^{\circ} 04^{\prime} 25^{\prime \prime} \mathrm{E}$ & wheat field & tilled & $>10,000$ & 2 & $11 / 07 / 2007$ \\
\hline
\end{tabular}


23. Raidestos, Wind 24. Sindos, TEI

25. Sindos, cultivated

26. Triadi, Kosmidis

27. Triadi, Namco
Thessaloniki $40^{\circ} 30^{\prime} 56^{\prime \prime} \mathrm{N}, 23^{\circ} 04^{\prime} 21^{\prime \prime} \mathrm{E}$ Thessaloniki $40^{\circ} 39^{\prime} 12^{\prime \prime} \mathrm{N}, 22^{\circ} 48^{\prime} 50^{\prime \prime} \mathrm{E}$

Thessaloniki $40^{\circ} 41^{\prime} 47^{\prime \prime} \mathrm{N}, 22^{\circ} 48^{\prime} 35^{\prime \prime} \mathrm{E}$

Thessaloniki $40^{\circ} 32^{\prime} 33^{\prime \prime} \mathrm{N}, 23^{\circ} 02^{\prime} 37^{\prime} \mathrm{E}$

Thessaloniki $40^{\circ} 32^{\prime} 57^{\prime \prime} \mathrm{N}, 23^{\circ} 02^{\prime} 09^{\prime \prime} \mathrm{E}$ semi-natural Mediterranean scrub wheat field

waste land, partly cultivated

wheat field left fallow

wheat field left fallow

$\begin{array}{llll}\text { surface } & >10,000 & 2 & 14 / 07 / 2007 \\ \text { tilled } & >10,000 & 2 & 19 / 07 / 2007 \\ \text { tillage } & >10,000 & 2 & 15 / 07 / 2007 \\ \text { tillage } & >10,000 & 2 & 20 / 07 / 2007 \\ \text { tillage } & >10,000 & 2 & 26 / 07 / 2007\end{array}$


Table 2. Aspects of allocation to female sex function, pollination success, and realized fecundity in the study populations. The symbol \# means "number of" and values are grand means for marked plants in each population \pm SE (sample size). Sample size is number of plants for plant height and fruits per plant; otherwise number of flowers. Visit rate includes only visits by pollinators that buzzed flowers. OP $=$ open-pollinated; PA $=$ cross pollen added by hand; PLI = Pollen Limitation Index. * = study population destroyed or damaged during the study.

\begin{tabular}{|c|c|c|c|c|c|c|c|c|}
\hline Study populations & $\begin{array}{l}\text { plant } \\
\text { height }(\mathrm{cm})\end{array}$ & $\begin{array}{l}\text { \# ovules } \\
\text { flower }^{-1}\end{array}$ & $\begin{array}{l}\text { \# flowers } \\
\text { per plant }\end{array}$ & $\begin{array}{l}\text { \# visits } \\
\text { flower }^{-1} \mathrm{~h}^{-1}\end{array}$ & $\begin{array}{l}\text { \# seeds/ } \\
\text { flower (OP) }\end{array}$ & $\begin{array}{l}\text { \# seeds/ } \\
\text { flower (PA) }\end{array}$ & PLI & $\begin{array}{l}\text { \# fruits } \\
\text { per plant }\end{array}$ \\
\hline \multicolumn{9}{|l|}{ Arizona } \\
\hline 1. Marana, Kai cotton & $\begin{array}{l}69.0 \pm 2.6 \\
(21)\end{array}$ & $\begin{array}{l}32.3 \pm 1.96 \\
(35)\end{array}$ & 713 & 0.046 & $\begin{array}{l}0.7 \pm 0.64 \\
(56)\end{array}$ & $\begin{array}{l}1.8 \pm 0.65 \\
(42)\end{array}$ & 0.61 & $\begin{array}{l}38.2 \pm 9.77 \\
(19)\end{array}$ \\
\hline 2. Marana, Kai fallow & $\begin{array}{l}62.3 \pm 1.7 \\
(29)\end{array}$ & $\begin{array}{l}71.0 \pm 2.27 \\
(73)\end{array}$ & - & 0.000 & $\begin{array}{l}0 \\
(75)\end{array}$ & $\begin{array}{l}2.7 \pm 0.96 \\
(73)\end{array}$ & 1 & $\begin{array}{l}2.2 \pm 1.05 \\
(18)\end{array}$ \\
\hline 3. Marana, Sanders cotton & $\begin{array}{l}54.7 \pm 1.3 \\
(41)\end{array}$ & $\begin{array}{l}69.1 \pm 3.38 \\
(30)\end{array}$ & 1205 & 0.027 & $\begin{array}{l}0.8 \pm 0.60 \\
(57)\end{array}$ & $\begin{array}{l}2.4 \pm 1.21 \\
(49)\end{array}$ & 0.67 & $\begin{array}{l}30.0 \pm 6.13 \\
(20)\end{array}$ \\
\hline 4. Marana, Sanders fallow & $\begin{array}{l}67.4 \pm 3.6 \\
(21)\end{array}$ & $\begin{array}{l}68.7 \pm 3.07 \\
(38)\end{array}$ & 387 & 0.014 & $\begin{array}{l}13.4 \pm 2.18 \\
(60)\end{array}$ & $\begin{array}{l}36.9 \pm 3.12 \\
(61)\end{array}$ & 0.64 & $\begin{array}{l}203.1 \pm 20.77 \\
(19)\end{array}$ \\
\hline 5. Santa Rita, lower & $\begin{array}{l}29.9 \pm 1.1 \\
(33)\end{array}$ & $\begin{array}{l}41.8 \pm 3.80 \\
(24)\end{array}$ & 44 & 0.034 & $\begin{array}{l}8.7 \pm 1.50 \\
(60)\end{array}$ & $\begin{array}{l}6.6 \pm 0.88 \\
(51)\end{array}$ & 0.00 & $\begin{array}{l}33.7 \pm 3.01 \\
(61)\end{array}$ \\
\hline 6. Santa Rita, upper & $\begin{array}{l}38.9 \pm 1.0 \\
(41)\end{array}$ & $\begin{array}{l}43.5 \pm 1.84 \\
(24)\end{array}$ & 46 & 0.252 & $\begin{array}{l}16.4 \pm 1.73 \\
(47)\end{array}$ & $\begin{array}{l}14.9 \pm 1.67 \\
(45)\end{array}$ & 0.00 & $\begin{array}{l}35.0 \pm 3.90 \\
(29)\end{array}$ \\
\hline 7. San Simon, huge & $\begin{array}{l}71.2 \pm 2.8 \\
(20)\end{array}$ & $\begin{array}{l}53.6 \pm 1.74 \\
(37)\end{array}$ & 371 & 0.044 & $\begin{array}{l}37.6 \pm 2.92 \\
(77)\end{array}$ & $\begin{array}{l}39.5 \pm 2.93 \\
(74)\end{array}$ & 0.05 & $\begin{array}{l}163.8 \pm 37.13 \\
(20)\end{array}$ \\
\hline 8. San Simon, Noland & $\begin{array}{l}63.4 \pm 2.0 \\
(21)\end{array}$ & $\begin{array}{l}64.5 \pm 3.19 \\
(37)\end{array}$ & 1636 & 0.015 & $\begin{array}{l}33.0 \pm 3.32 \\
(68)\end{array}$ & $\begin{array}{l}46.2 \pm 3.94 \\
(60)\end{array}$ & 0.29 & $\begin{array}{l}120.4 \pm 22.84 \\
(30)\end{array}$ \\
\hline 9. Willcox, Moonlight & $\begin{array}{l}31.1 \pm 0.9 \\
(54)\end{array}$ & $\begin{array}{l}52.9 \pm 2.39 \\
(31)\end{array}$ & 40 & 0.195 & $\begin{array}{l}11.9 \pm 3.33 \\
(41)\end{array}$ & $\begin{array}{l}50.9 \pm 4.70 \\
(29)\end{array}$ & 0.77 & $\begin{array}{l}17.5 \pm 3.76 \\
(32)\end{array}$ \\
\hline \multicolumn{9}{|l|}{ Greece } \\
\hline 10. Arisvi & $\begin{array}{l}73.0 \pm 1.5 \\
(30)\end{array}$ & $\begin{array}{l}49.5 \pm 1.53 \\
(30)\end{array}$ & 253 & 1.130 & $\begin{array}{l}8.7 \pm 1.81 \\
(57)\end{array}$ & $\begin{array}{l}24.1 \pm 2.86 \\
(58)\end{array}$ & 0.64 & $\begin{array}{l}102.0 \pm 16.59 \\
(30)\end{array}$ \\
\hline 11. Eressos* & - & $49.9 \pm 6.63$ & - & 0.620 & $48.7 \pm 4.30$ & $60.7 \pm 5.13$ & 0.20 & - \\
\hline
\end{tabular}




\begin{tabular}{|c|c|c|c|c|c|c|c|c|}
\hline & & (13) & & & (46) & (42) & & \\
\hline 12. Plomari & $\begin{array}{l}63.7 \pm 1.7 \\
(30)\end{array}$ & $\begin{array}{l}52.5 \pm 1.79 \\
(30)\end{array}$ & 157 & 0.170 & $\begin{array}{l}0.1 \pm 0.03 \\
(59)\end{array}$ & $\begin{array}{l}0.1 \pm 0.05 \\
(59)\end{array}$ & 0 & $\begin{array}{l}15.9 \pm 2.01 \\
(30)\end{array}$ \\
\hline 13. Anchialos, Cemetery & $\begin{array}{l}68.4 \pm 1.9 \\
(29)\end{array}$ & $\begin{array}{l}94.6 \pm 4.39 \\
(60)\end{array}$ & 1234 & 0.000 & $\begin{array}{l}2.1 \pm 1.94 \\
(58)\end{array}$ & $\begin{array}{l}4.7 \pm 1.40 \\
(58)\end{array}$ & 0.55 & $\begin{array}{l}41.1 \pm 5.40 \\
(25)\end{array}$ \\
\hline 14. Anchialos, Farmakis & $\begin{array}{l}71.1 \pm 1.9 \\
(30)\end{array}$ & $\begin{array}{l}108.6 \pm 4.86 \\
(56)\end{array}$ & 394 & 0.000 & $\begin{array}{l}1.7 \pm 1.13 \\
(60)\end{array}$ & $\begin{array}{l}71.9 \pm 4.86 \\
(60)\end{array}$ & 0.98 & $\begin{array}{l}59.1 \pm 7.82 \\
(26)\end{array}$ \\
\hline 15. Anchialos, Ioannou & $\begin{array}{l}68.4 \pm 2.0 \\
(30)\end{array}$ & $\begin{array}{l}106.9 \pm 3.91 \\
(60)\end{array}$ & 315 & 0.000 & $\begin{array}{l}1.4 \pm 1.20 \\
(60)\end{array}$ & $\begin{array}{l}68.6 \pm 5.31 \\
(60)\end{array}$ & 0.98 & $\begin{array}{l}52.5 \pm 7.22 \\
(26)\end{array}$ \\
\hline 16. Anchialos, Narlis* & - & $\begin{array}{l}111.5 \pm 6.16 \\
(60)\end{array}$ & - & - & - & - & - & - \\
\hline 17. Anchialos, Toumba* & - & $\begin{array}{l}77.78 \pm 3.77 \\
(60)\end{array}$ & - & 0.000 & $\begin{array}{l}0 \\
(30)\end{array}$ & $\begin{array}{l}64.6 \pm 7.93 \\
(30)\end{array}$ & 1 & - \\
\hline 18. Anchialos, Vaggelis & $\begin{array}{l}76.1 \pm 1.7 \\
(30)\end{array}$ & $\begin{array}{l}113.3 \pm 5.15 \\
(60)\end{array}$ & 647 & 0.000 & $\begin{array}{l}0.3 \pm 0.16 \\
(60)\end{array}$ & $\begin{array}{l}66.6 \pm 6.29 \\
(60)\end{array}$ & 1 & $\begin{array}{l}43.1 \pm 5.51 \\
(29)\end{array}$ \\
\hline 19. Panorama & $\begin{array}{l}65.1 \pm 2.4 \\
(30)\end{array}$ & $\begin{array}{l}104.7 \pm 7.39 \\
(60)\end{array}$ & 317 & 0.008 & $\begin{array}{l}0.9 \pm 0.35 \\
(60)\end{array}$ & $\begin{array}{l}56.9 \pm 10.59 \\
(60)\end{array}$ & 0.98 & $\begin{array}{l}52.9 \pm 6.99 \\
(30)\end{array}$ \\
\hline 20. Raidestos, Atlanta & $\begin{array}{l}54.3 \pm 2.5 \\
(30)\end{array}$ & $\begin{array}{l}99.8 \pm 5.03 \\
(60)\end{array}$ & 103 & 0.000 & $\begin{array}{l}2.9 \pm 1.58 \\
(60)\end{array}$ & $\begin{array}{l}51.0 \pm 5.60 \\
(60)\end{array}$ & 0.94 & $\begin{array}{l}19.0 \pm 3.85 \\
(24)\end{array}$ \\
\hline 21. Raidestos, onion & $\begin{array}{l}52.5 \pm 1.8 \\
(30)\end{array}$ & $\begin{array}{l}98.2 \pm 5.26 \\
(61)\end{array}$ & 195 & 0.000 & $\begin{array}{l}2.5 \pm 1.68 \\
(60)\end{array}$ & $\begin{array}{l}61.8 \pm 4.21 \\
(60)\end{array}$ & 0.96 & $\begin{array}{l}22.0 \pm 2.94 \\
(31)\end{array}$ \\
\hline 22. Raidestos, wheat & $\begin{array}{l}65.2 \pm 1.6 \\
(30)\end{array}$ & $\begin{array}{l}109.6 \pm 3.90 \\
(60)\end{array}$ & 75 & 0.000 & $\begin{array}{l}0.7 \pm 0.38 \\
(60)\end{array}$ & $\begin{array}{l}28.3 \pm 4.37 \\
(60)\end{array}$ & 0.98 & $\begin{array}{l}6.2 \pm 2.36 \\
(25)\end{array}$ \\
\hline 23. Raidestos, Wind & $\begin{array}{l}58.3 \pm 1.5 \\
(31)\end{array}$ & $\begin{array}{l}117.3 \pm 5.09 \\
(60)\end{array}$ & 109 & 0.000 & $\begin{array}{l}0.5 \pm 0.20 \\
(62)\end{array}$ & $\begin{array}{l}63.8 \pm 4.80 \\
(62)\end{array}$ & 0.99 & $\begin{array}{l}14.1 \pm 3.15 \\
(25)\end{array}$ \\
\hline 24. Sindos, TEI* & - & $\begin{array}{l}119.3 \pm 5.44 \\
(72)\end{array}$ & - & 0.000 & $\begin{array}{l}2.3 \pm 1.65 \\
(70)\end{array}$ & $\begin{array}{l}67.0 \pm 6.55 \\
(70)\end{array}$ & 0.97 & - \\
\hline 25. Sindos, cultivated & $\begin{array}{l}84.3 \pm 2.3 \\
(37)\end{array}$ & $\begin{array}{l}91.1 \pm 3.90 \\
(73)\end{array}$ & 416 & 0.000 & $\begin{array}{l}2.7 \pm 1.25 \\
(72)\end{array}$ & $\begin{array}{l}64.1 \pm 4.17 \\
(72)\end{array}$ & 0.96 & $\begin{array}{l}56.2 \pm 8.77 \\
(33)\end{array}$ \\
\hline 26. Triadi, Kosmidis & $\begin{array}{l}51.5 \pm 1.8 \\
(30)\end{array}$ & $\begin{array}{l}113.1 \pm 5.25 \\
(60)\end{array}$ & 311 & 0.000 & $\begin{array}{l}2.0 \pm 1.22 \\
(58)\end{array}$ & $\begin{array}{l}54.9 \pm 5.00 \\
(58)\end{array}$ & 0.96 & $\begin{array}{l}20.7 \pm 5.75 \\
(15)\end{array}$ \\
\hline 27. Triadi, Namco & $\begin{array}{l}63.4 \pm 1.4 \\
(30)\end{array}$ & $\begin{array}{l}114.1 \pm 4.61 \\
(60)\end{array}$ & 1022 & 0.000 & $\begin{array}{l}0.8 \pm 0.80 \\
(60)\end{array}$ & $\begin{array}{l}48.1 \pm 3.99 \\
(60)\end{array}$ & 0.98 & $\begin{array}{l}17.0 \pm 1.95 \\
(29)\end{array}$ \\
\hline
\end{tabular}


Table 3. Bee taxa recorded on Solanum elaeagnifolium flowers in our study populations, as indicated by "+". All taxa "buzzed" flowers, and thus are considered major pollinators, except those marked with *. Lesvos populations were regularly visited by non-buzzing honeybees that collected spilled pollen.

\begin{tabular}{|c|c|c|c|c|c|c|c|c|c|c|c|c|c|c|}
\hline \multirow[b]{2}{*}{ Population } & \multicolumn{9}{|c|}{ Apidae } & \multicolumn{2}{|c|}{ Andrenidae } & \multicolumn{2}{|c|}{ Halictidae } & \multirow[b]{2}{*}{ 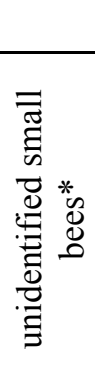 } \\
\hline & 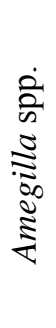 & 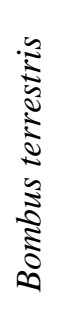 & 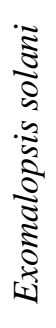 & 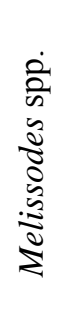 & 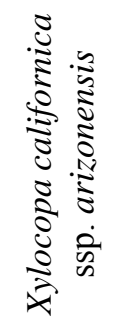 & 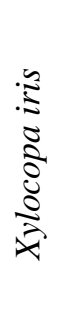 & 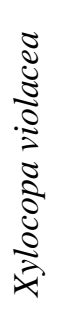 & 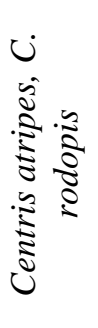 & 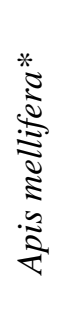 & 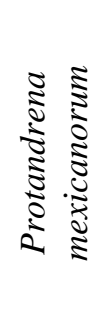 & $\begin{array}{l}0 \\
0 \\
0 \\
0 \\
0 \\
0 \\
0 \\
0 \\
0 \\
0 \\
0 \\
0 \\
0 \\
0\end{array}$ & 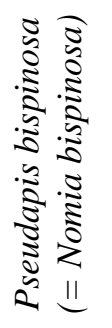 & 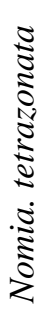 & \\
\hline Arizona & & & & & & & & & & & & & & \\
\hline 1. Marana, Kai cotton & - & - & + & + & + & - & - & - & - & - & + & - & + & + \\
\hline 2. Marana, Kai fallow & - & - & + & + & + & - & - & - & - & - & + & - & + & + \\
\hline $\begin{array}{l}\text { 3. Marana, Sanders } \\
\text { cotton }\end{array}$ & - & - & + & + & + & - & - & - & - & - & + & - & + & + \\
\hline $\begin{array}{l}\text { 4. Marana, Sanders } \\
\text { fallow }\end{array}$ & - & - & + & + & + & - & - & - & - & - & + & - & + & + \\
\hline 5. Santa Rita, lower & - & - & - & - & + & - & - & + & - & + & + & - & + & + \\
\hline 6. Santa Rita, upper & - & - & - & - & + & - & - & + & - & + & + & - & + & + \\
\hline 7. San Simon, huge & - & - & - & - & - & - & - & - & - & - & + & - & - & + \\
\hline 8. San Simon, Noland & - & - & - & - & - & - & - & - & - & - & + & - & - & + \\
\hline 9. Willcox, Moonlight & - & - & + & - & + & - & - & - & - & - & - & - & - & + \\
\hline Greece & - & - & - & - & - & - & - & - & - & - & - & - & - & \\
\hline 10. Arisvi & - & + & - & - & - & + & - & - & + & - & - & + & - & + \\
\hline 11. Eressos & + & + & & & & + & & & & & & + & & + \\
\hline 12. Plomari & - & - & - & - & - & + & - & - & + & - & - & + & - & + \\
\hline 13. Anchialos, Cemetery & - & - & - & - & - & - & - & - & - & - & - & - & - & - \\
\hline 14. Anchialos, Farmakis & - & - & - & - & - & - & - & - & - & - & - & - & - & - \\
\hline 15. Anchialos, Ioannou & - & - & - & - & - & - & - & - & - & - & - & - & - & - \\
\hline 16. Anchialos, Narlis & - & - & - & - & - & - & - & - & - & - & - & - & - & - \\
\hline 17. Anchialos, Toumba & - & - & - & - & - & - & - & - & - & - & - & - & - & - \\
\hline 18. Anchialos, Vaggelis & - & - & - & - & - & - & - & - & - & - & - & - & - & - \\
\hline 19. Panorama & + & + & - & - & - & - & - & - & - & - & - & - & - & - \\
\hline 20. Raidestos, Atlanta & - & - & - & - & - & - & - & - & - & - & - & - & - & - \\
\hline 21. Raidestos, onion & - & - & - & - & - & - & - & - & - & - & - & - & - & - \\
\hline 22. Raidestos, wheat & - & - & - & - & - & - & - & - & - & - & - & - & - & - \\
\hline 23. Raidestos, Wind & - & - & - & - & - & - & - & - & - & - & - & - & - & - \\
\hline 24. Sindos, TEI & - & - & - & - & - & - & - & - & - & - & - & - & - & - \\
\hline 25. Sindos, cultivated & - & - & - & - & - & - & - & - & - & - & - & - & - & - \\
\hline 26. Triadi, Kosmidis & - & - & - & - & - & - & - & - & - & - & - & - & - & - \\
\hline 27. Triadi, Namco & - & - & - & - & - & - & - & - & - & - & - & - & - & - \\
\hline
\end{tabular}


Fig. 1. Relationship between mean plant height and population size score. Plant stature increased with population size in our US (open circles) but not in our GR (filled circles) populations.

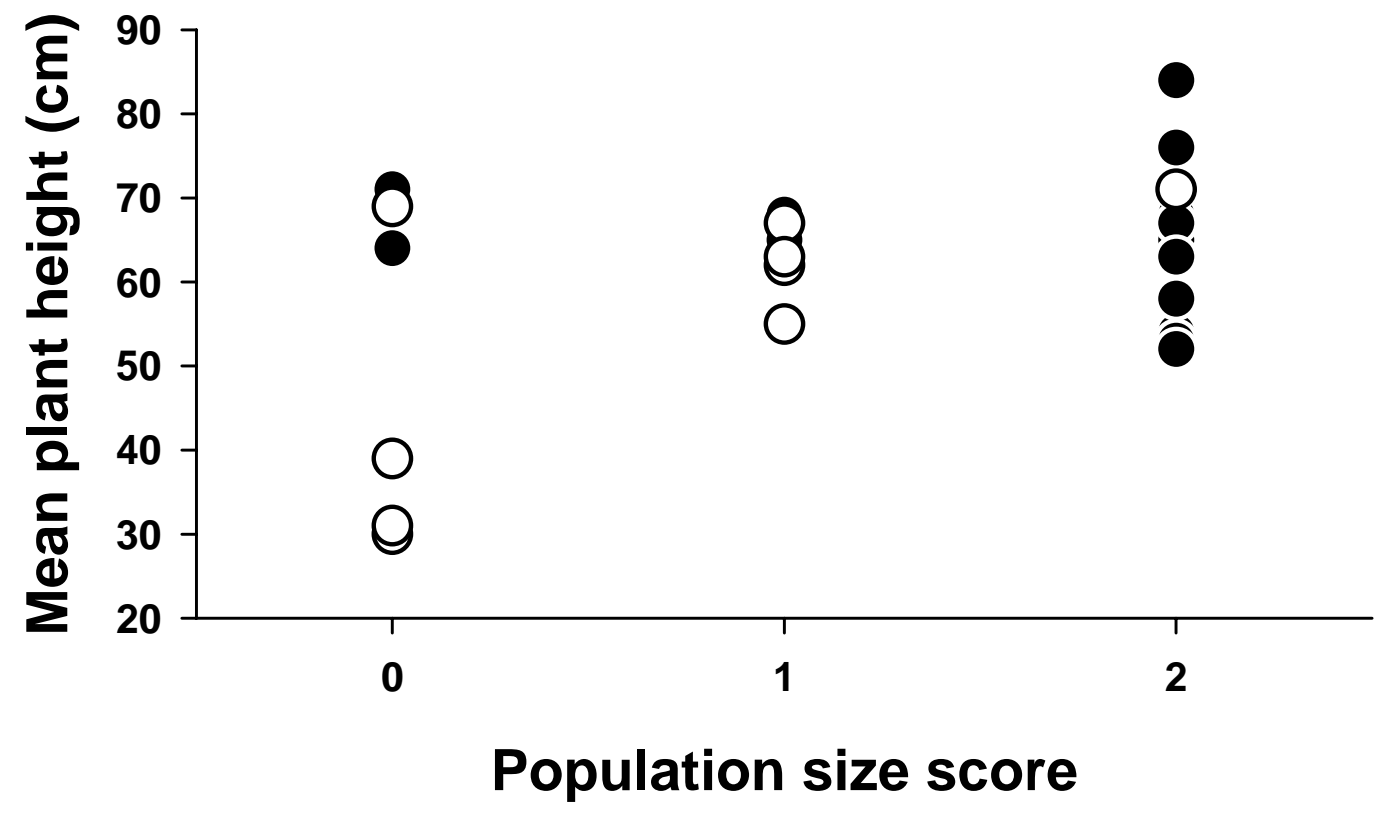


Fig. 2. Estimated total flowers per plant as a function of plant stature. Flower number increased with plant height in both our US (open circles) and in our GR (filled circles) populations; US plants were smaller on average and produced fewer flowers on average.

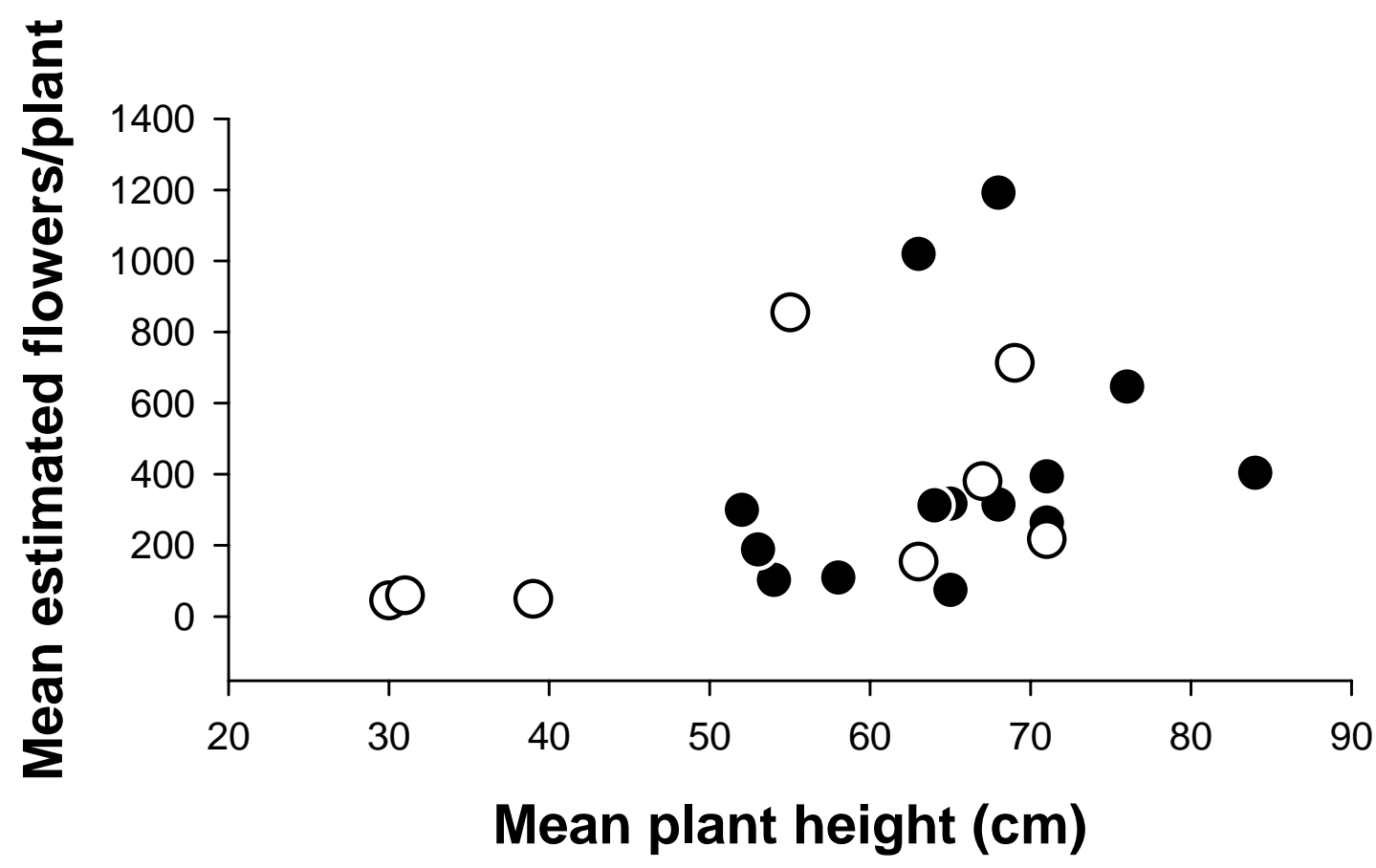


Fig. 3. Nonlinear increase in ovule number per flower with population size. In both our US (open circles) and in our GR (filled circles) populations, ovule number increased to an apparent plateau, which was lower in the US sample.

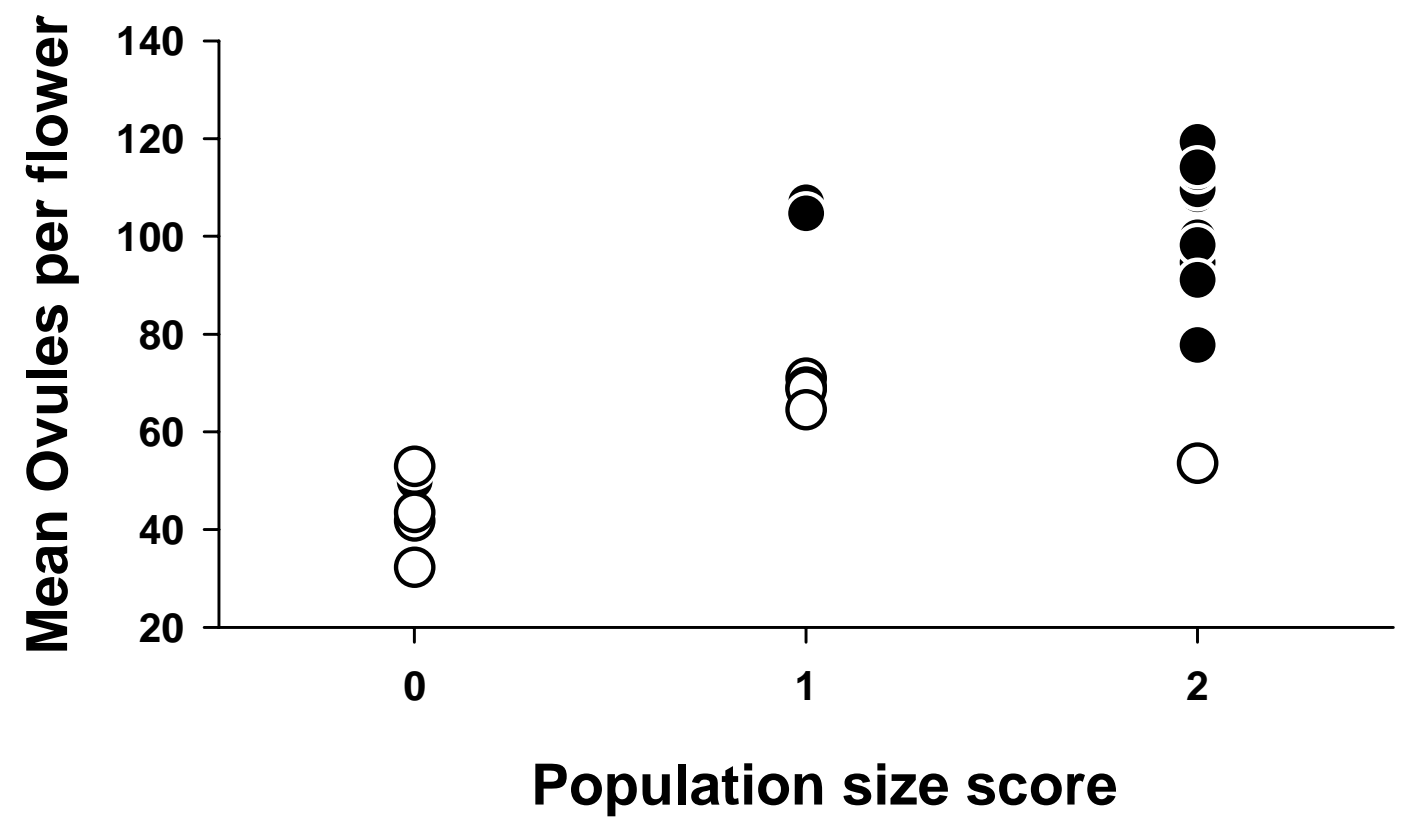


Fig. 4. Nonlinear decrease in pollinator visits with size of our US (open circles) and GR (filled circles) populations. Observed visitation rates were higher in smaller populations, and highest in two populations on Lesvos; they declined to very low values or to zero in the largest populations, especially those around Thessaloniki.

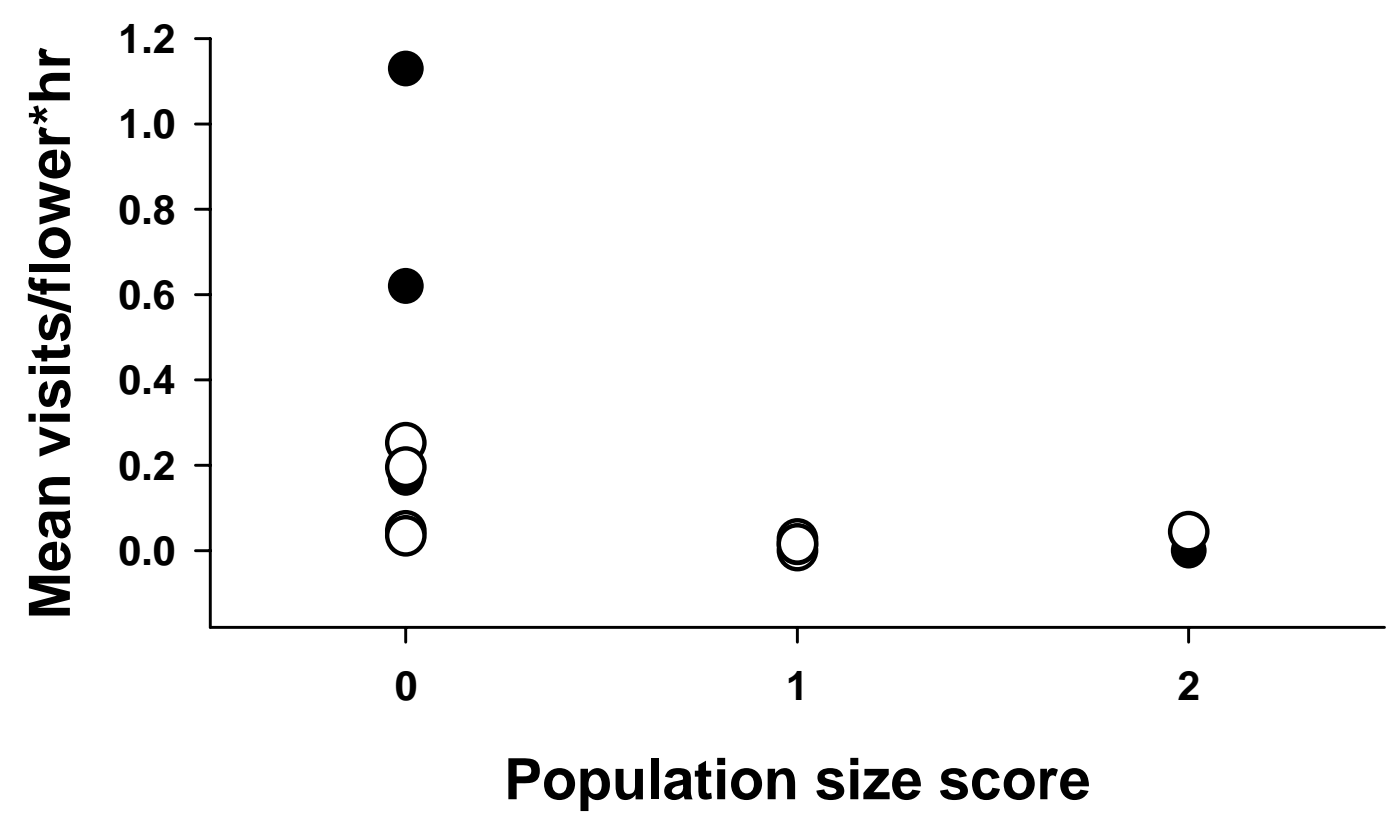


Fig. 5. Pollen Limitation Index vs. pollinator visit rate. PLI decreased with pollinator visit rate in both our US (open circles) and in our GR (filled circles) populations, although the range of visit rates was far greater in GR.

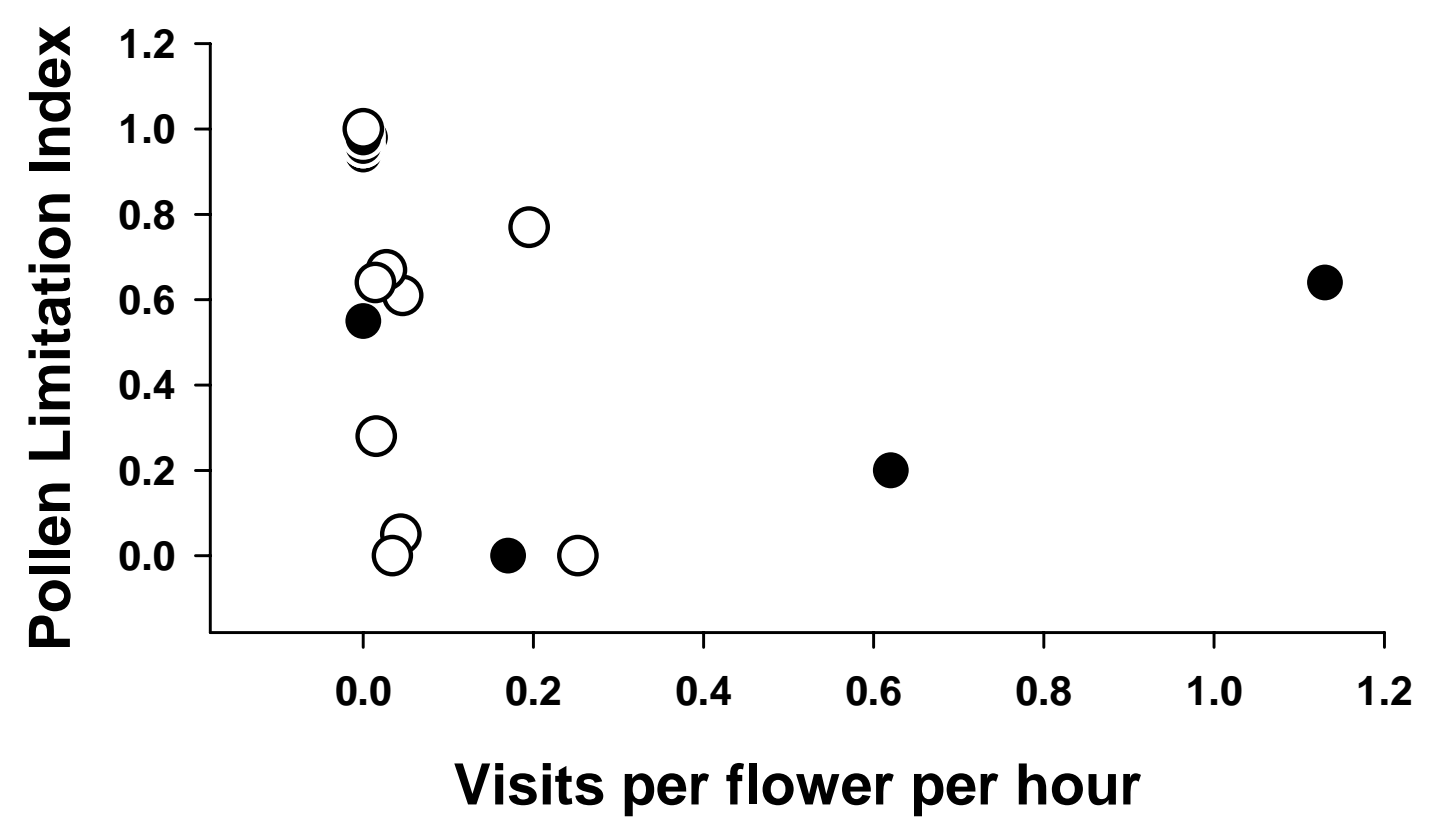


Fig. 6. Total fruits per plant vs. plant stature. Fruit production increased close to linearly with plant height in both our US (open circles) and in our GR (filled circles) populations, but the overall mean was greater for US plants.

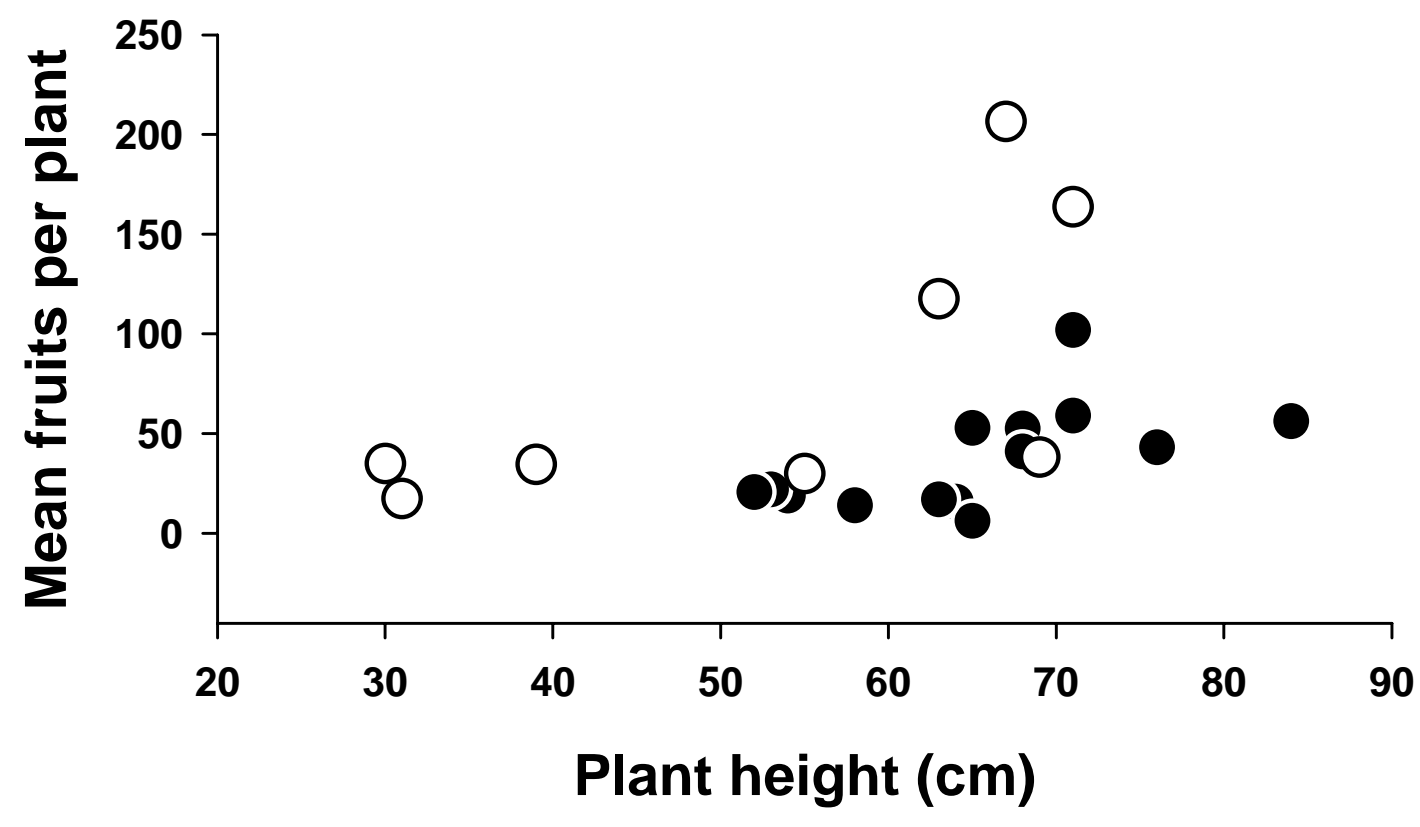


Fig. 7. Seeds per flower vs. pollinator visit rate. Mean seed set increased with visits in both our US (open circles) and in our GR (filled circles) populations. Flowers produced more seeds on average in US than in GR populations; it is not obvious from the figure that 15 GR populations are clustered near the origin $(0,0)$, as Table 2 shows.

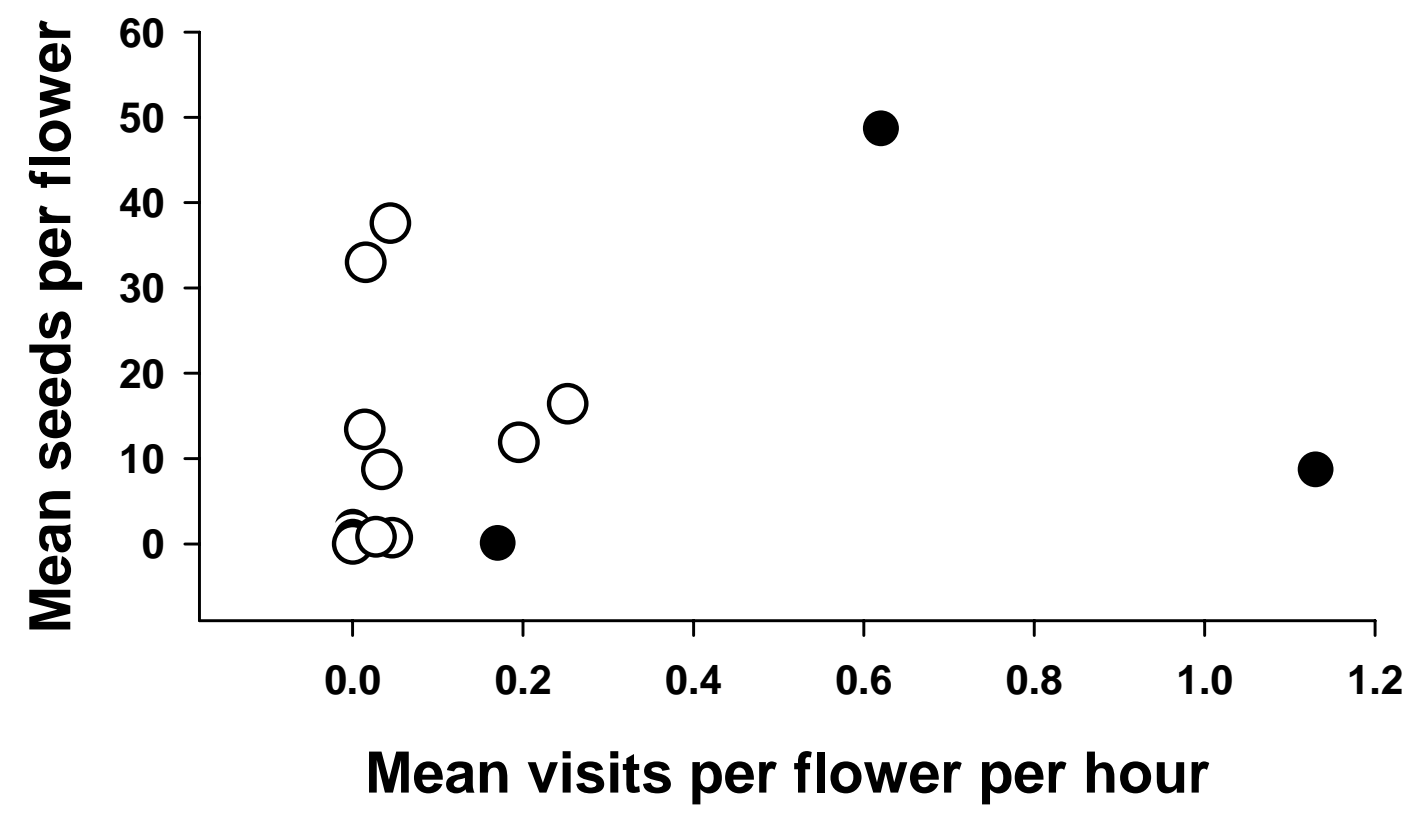


Table S1. Details of statistical models from which results reported in the text are derived.

"VARIABLE" = response variable; SOURCE = predictor variable; "Country" = country of origin of the sample of study populations; "Pop size" = population size score $(0,1$, or 2$)$ treated as a continuous variable; "Disturbance" = type of soil disturbance (surface vs. tilled) experienced by a population. Two alternative analyses are included for fruits per plant, as described in the text. The analysis of seeds per flower refers to marked flowers in the open-pollinated (OP) treatment.

\begin{tabular}{|c|c|c|c|c|c|}
\hline VARIABLE & SOURCE & $\mathrm{Df}$ & $\mathrm{F}$ & $\mathrm{P}$ & COMMENTS \\
\hline $\ln$ (Plant height) & Country & $1,19.20$ & 0.821 & 0.376 & REML ANCOVA \\
\hline \multirow[t]{4}{*}{ Model $\mathrm{R}_{\text {adi }}^{2}=0.724$} & Pop size & $1,19.17$ & 2.554 & 0.126 & based on 775 \\
\hline & Disturbance & $1,19.14$ & 4.875 & 0.040 & individual values; \\
\hline & Country $\times$ pop size & $1,19.17$ & 4.252 & 0.053 & only fixed effect \\
\hline & Country $\times$ disturbance & $1,19.14$ & 4.664 & 0.044 & tests given \\
\hline $\ln$ (Flowers/plant) & Country & 1,18 & 0.034 & 0.879 & ANCOVA \\
\hline \multirow{2}{*}{ Model $\mathrm{R}_{\text {adj }}^{2}=0.364$} & Plant height & 1,18 & 10.077 & 0.005 & based on \\
\hline & Country $\times$ plant height & 1,18 & 0.251 & 0.623 & population means \\
\hline $\ln ($ Ovules/flower) & Country & 1,17 & 102.488 & $<0.0001$ & Polynomial \\
\hline \multirow[t]{4}{*}{ Model $\mathrm{R}_{\text {adj }}^{2}=0.951$} & Plant height & 1,17 & 9.537 & 0.007 & ANCOVA \\
\hline & Pop size & 1,17 & 9.227 & 0.007 & based on \\
\hline & Pop size ${ }^{2}$ & 1,17 & 62.645 & $<0.0001$ & population means \\
\hline & Country $\times$ pop size & 1,17 & 4.666 & 0.045 & \\
\hline$\sqrt{ }($ Visits/flower/hour) & Country & 1,21 & 0.170 & 0.685 & Polynomial \\
\hline \multirow{3}{*}{ Model $\mathrm{R}_{\text {adj }}^{2}=0.786$} & Pop size & 1,21 & 2.664 & 0.118 & ANCOVA \\
\hline & Pop size ${ }^{2}$ & 1,21 & 13.507 & 0.0014 & based on \\
\hline & Country $\times$ pop size & 1,21 & 17.283 & 0.0001 & population means \\
\hline PLI & Country & 1,21 & 10.865 & 0.0034 & ANCOVA \\
\hline \multirow{2}{*}{ Model $\mathrm{R}_{\text {adj }}^{2}=0.490$} & $\sqrt{ }($ Visits/flower/hour) & 1,21 & 5.352 & 0.031 & based on \\
\hline & $\begin{array}{l}\text { Country } \times \\
\sqrt{ }(\text { Visits/flower/hour })\end{array}$ & 1,21 & 0.341 & 0.566 & population means \\
\hline \multirow{3}{*}{$\begin{array}{l}\ln (\text { Fruits/plant) } \\
\text { Model } R_{\text {adj }}^{2}=0.409\end{array}$} & Country & 1,17 & 12.243 & 0.0027 & ANCOVA \\
\hline & $\ln$ (Plant height) & 1,17 & 11.211 & 0.0038 & based on \\
\hline & $\begin{array}{l}\text { Country } \times \ln \text { (plant } \\
\text { height) }\end{array}$ & 1,17 & 0.808 & 0.381 & population means \\
\hline \multirow{3}{*}{$\begin{array}{l}\ln (\text { Fruits/plant) } \\
\text { Model }_{\text {adj }}^{2}=0.449\end{array}$} & PLI & 1,17 & 14.008 & 0.0016 & ANCOVA \\
\hline & $\ln$ (Plant height) & 1,17 & 9.026 & 0.008 & based on \\
\hline & PLI $\times \ln ($ plant height $)$ & 1,17 & 0.148 & 0.706 & population means \\
\hline \multirow{3}{*}{$\begin{array}{l}\sqrt{ }(\text { Seeds } / \text { flower }) \\
\text { Model } R_{\text {adj }}^{2}=0.338\end{array}$} & Country & 1,21 & 2.605 & 0.121 & ANCOVA \\
\hline & $\sqrt{ }$ Visits/flower/hour & 1,21 & 4.479 & 0.046 & based on \\
\hline & $\begin{array}{l}\text { Country } \times \\
\sqrt{ }(\text { Visits/flower/hour })\end{array}$ & 1,21 & 0.012 & 0.914 & population means \\
\hline
\end{tabular}


Fig. S1. An invasive desert near Anchialos, in the western metropolitan area of

Thessaloniki - a large area taken over by a very aggressive monospecific stand of $S$.

elaeagnifolium (image: T. Petanidou).

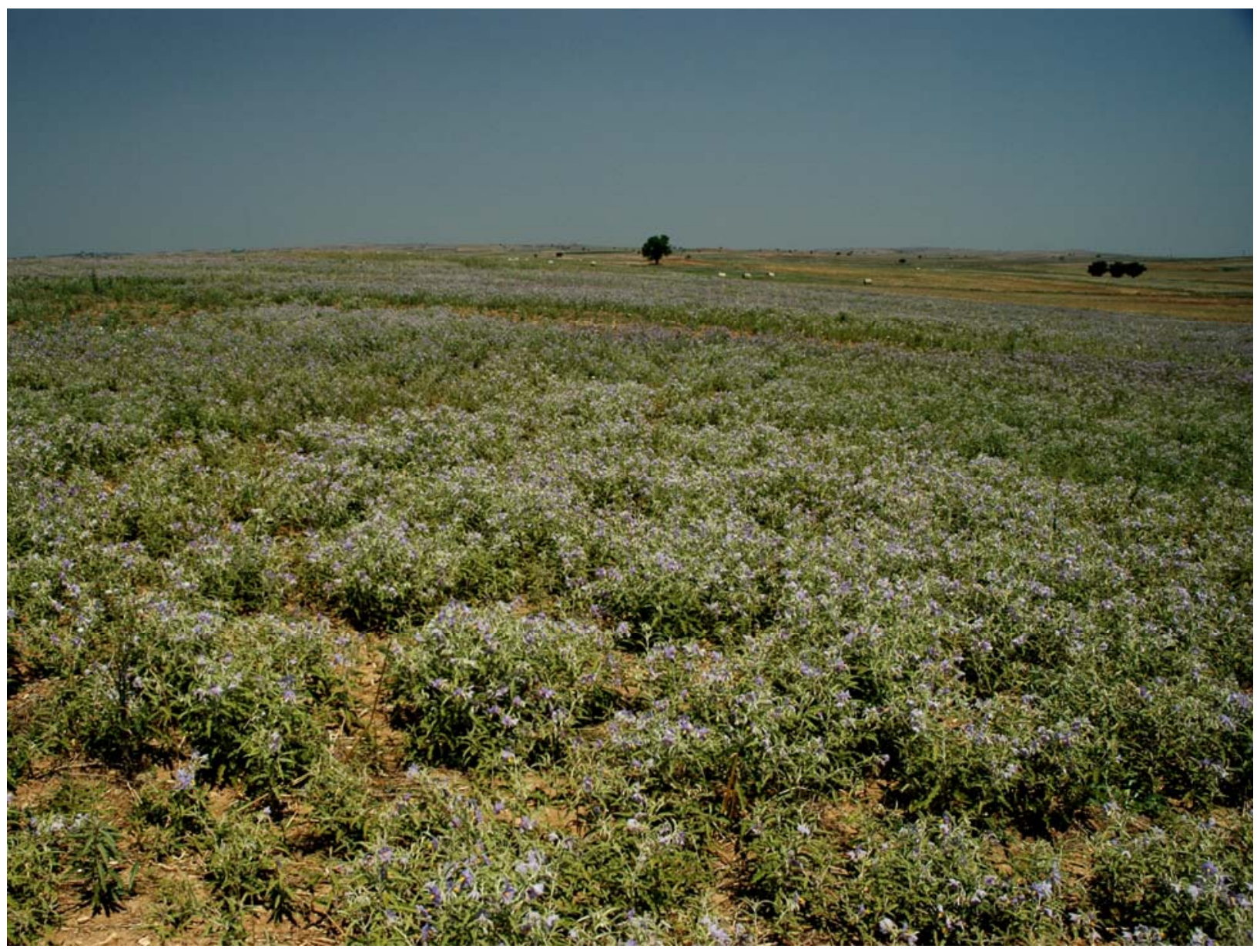


Fig. S2. A smaller, less aggressive population of S. elaeagnifolium in the countryside near Willcox, Arizona (image: T. Petanidou).

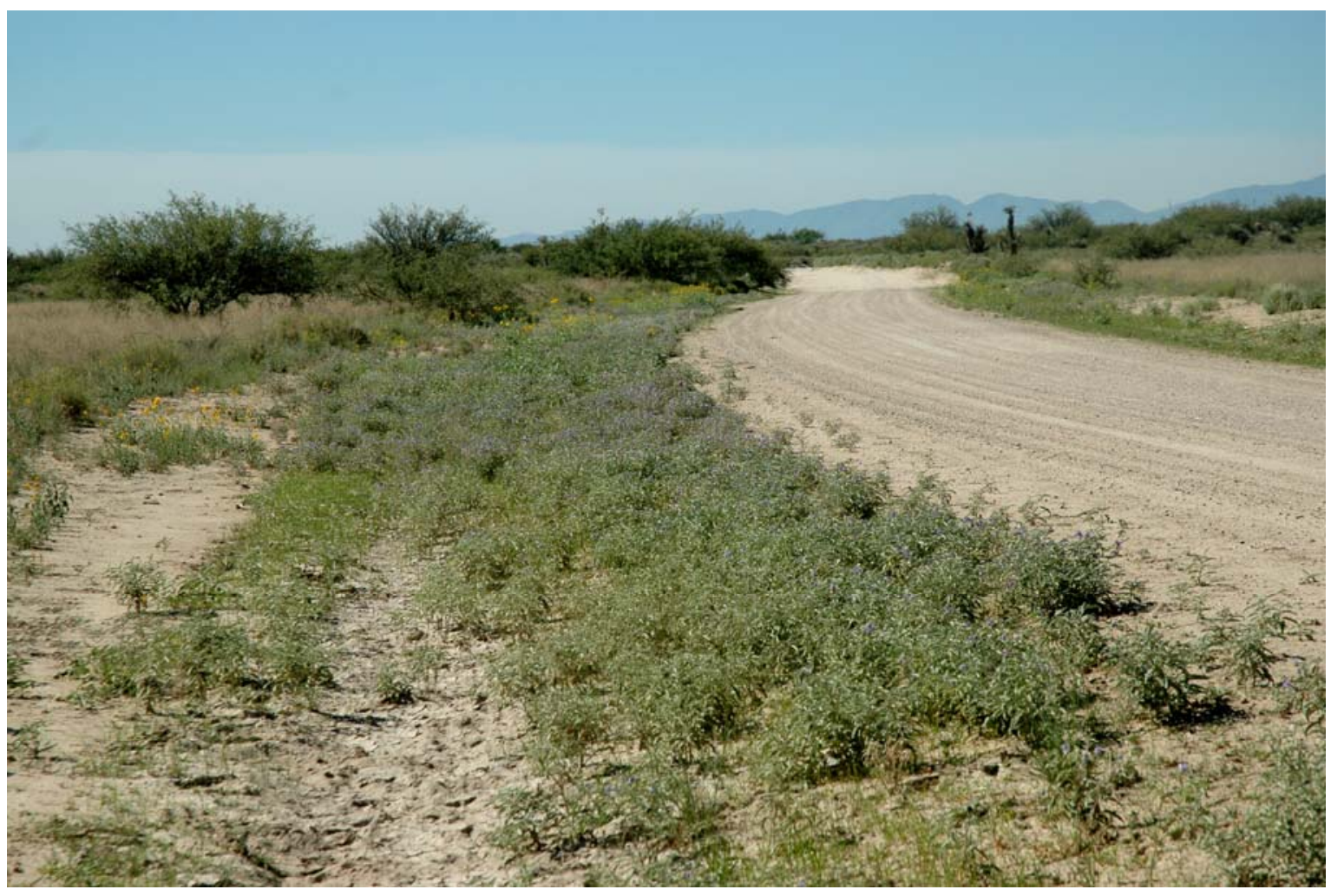

